\title{
10. CENOZOIC PLANKTONIC FORAMINIFERAL BIOSTRATIGRAPHY OF THE GOBAN SPUR REGION, DEEP SEA DRILLING PROJECT LEG 80 ${ }^{1}$
}

\author{
Scott W. Snyder and Virginia J. Waters, Department of Geology, East Carolina University ${ }^{2}$
}

\begin{abstract}
Cenozoic planktonic foraminiferal biostratigraphy at DSDP-IPOD Leg 80 sites documents the existence of regionwide stratigraphic gaps in the Paleocene and middle Miocene. Episodes of carbonate dissolution also occurred during the Paleocene at several sites, particularly at Site 549, where destruction of foraminiferal tests may obscure evidence of an unconformity. The middle Miocene hiatus is apparent at each site where Neogene sediments were continuously cored. Upper Miocene sediments at Site 550 (the only abyssal site) are characterized by moderate to extensive dissolution of planktonic foraminifers, but they contain abundant specimens of Bolboforma that mark this stratigraphic interval (von Daniels and Spiegler, 1974; Roegl, 1976; Murray, 1979; Müller et al., this vol.). Although foraminiferal evidence is not conclusive, nannofossils indicate a widespread Oligocene unconformity (Müller, this vol.). Several oceanographic factors, not just simple sea-level change, probably interacted to produce these regional unconformities.

There are also dramatic differences in the Cenozoic sedimentary record among Leg 80 sites, indicating that each has had a distinct geologic history. The thickness of the Cenozoic section varies from $100 \mathrm{~m}$ at Site 551 to $471 \mathrm{~m}$ at Site 548 . The thickness of individual chronostratigraphic units also varies, as do the number and stratigraphic position of unconformities other than those mentioned. Differences in the stratigraphic record from site to site across the continental slope result from (1) location in separate half-graben structures, (2) varying location across the developing margin, and (3) difference in position relative to the seaward edge of the enclosing half-graben. Except for turbidites, deposition at Site 550 (abyssal) was largely independent of developments on the continental slope; but it was affected by oceanographic events widespread in the North Atlantic.
\end{abstract}

\section{INTRODUCTION}

On Deep Sea Drilling Project Leg 80 (Brest, France to Southampton, United Kingdom), four sites were drilled along a roughly east-west transect across the Goban Spur and onto the adjacent Porcupine Abyssal Plain. The basement in this area is broken by a series of listric normal faults into tilted blocks and intervening halfgrabens (Fig. 1). Thick syn-rift and post-rift sediment sequences fill the half-grabens, then thin or gradually pinch out over tilted blocks that bound their seaward edges. Although Mesozoic sediments are more dramatically affected, Cenozoic units thin and also occasionally disappear toward the seaward margins of the half-grabens.

Sites 548, 549, and 551 lie at or near the seaward edges of three different half-grabens located progressively farther westward on the Goban Spur. Site 550 lies on the Porcupine Abyssal Plain about $10 \mathrm{~km}$ to the southwest of the Goban Spur. Most or all of the Cenozoic section was continuously cored at Sites 548,549 , and 550 . Because the upper portion of Hole 551 was washed to 100 meters sub-bottom, only three spot-cores were taken within Cenozoic sediments.

Planktonic foraminifers are generally abundant and well preserved throughout the Cenozoic sediments recovered at these sites. Notable exceptions to this preservational pattern occur in the middle through upper Mio-

\footnotetext{
${ }^{1}$ Graciansky, P. C. de, Poag, C. W., et al., Init. Repts. DSDP, 80: Washington (U.S. Govt, Printing Office).

2 Address: Dept. of Geology, East Carolina University, Greenville, NC 27834; (Waters, present address) Texaco, U.S.A., New Orleans, LA 70160.
}

cene and the middle through upper Eocene at Site 550. Much of the upper Paleocene sedimentary section at Sites 549 and 550 is also barren or contains only rare and poorly preserved specimens. The Miocene sediments contain abundant Bolboforma; the Eocene and Paleocene sediments contain abundant siliceous remains (radiolarians, spicules). Benthic foraminifers are usually present but generally rare throughout the Cenozoic section; ostracodes occur sporadically and are always rare.

The purpose of this chapter is to present the planktonic foraminiferal biostratigraphy of Cenozoic sediments at Leg 80 sites. Shipboard analyses were based almost exclusively upon core-catcher samples. For the purposes of this study, additional samples were taken from each section of every core. Depending upon the nature of the stratigraphic section and the need for biostratigraphic detail, the number of samples examined varied from one per core to one per section. The interpretations presented here are based largely upon the more detailed sampling within the sediment cores (approximately 350 samples from the three sites where the Cenozoic was continuously cored). Data from core-catcher samples are used only where they provide significant additional detail.

All samples were prepared by soaking in a dilute solution of Calgon and then washing on a \#230 U.S. Standard Sieve (63- $\mu \mathrm{m}$ openings). The dried residue trapped on the sieve was placed in a $0.1 \mathrm{M}$ solution of sodium pyrophosphate and gently agitated for 20 to $30 \mathrm{~min}$. This process greatly aided species identification by effectively removing persistent clay-sized particles from sutures and apertures without causing any noticeable abrasion of surface features. 


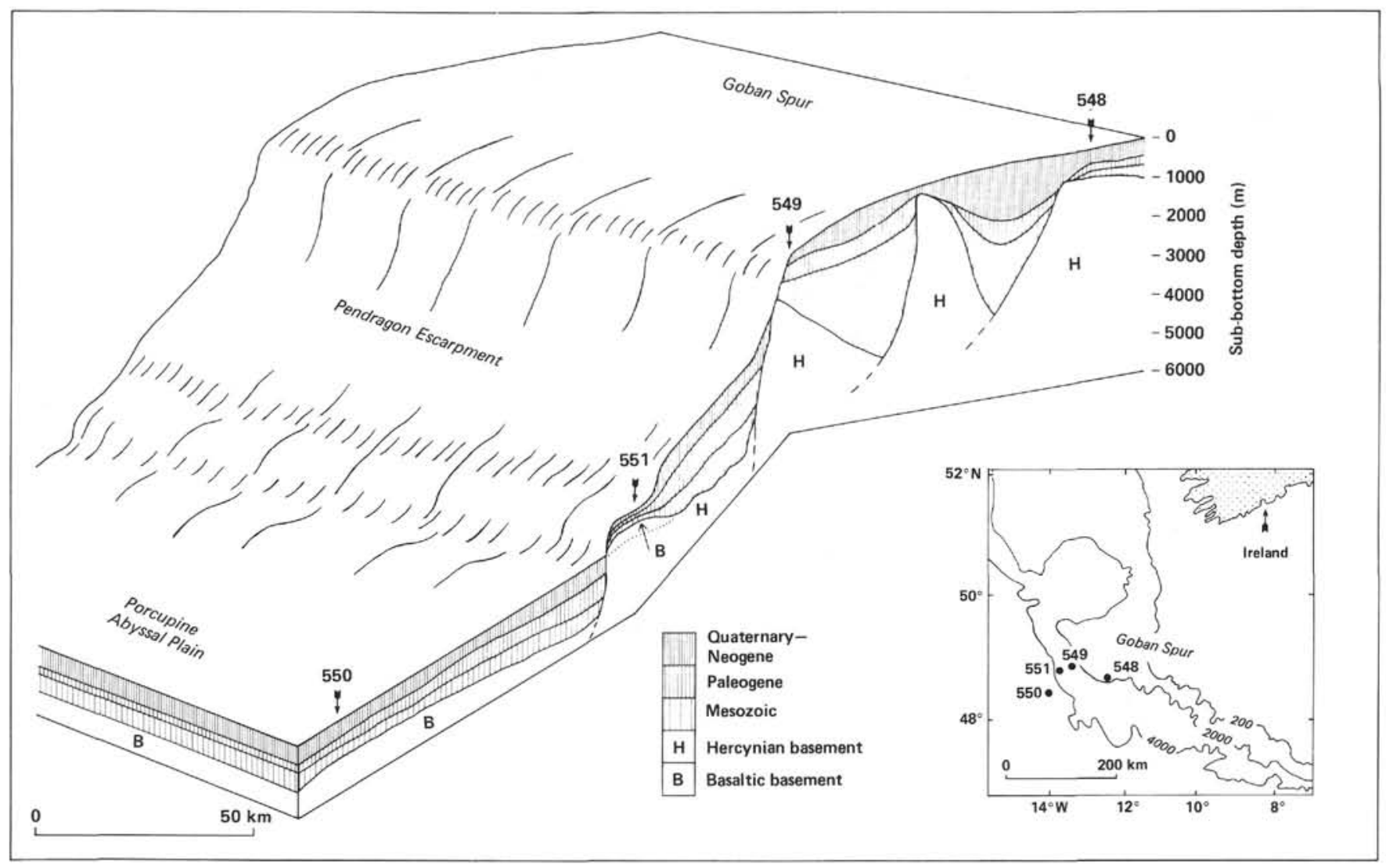

Figure 1. Locations and generalized geologic settings of Leg 80 drill sites across the Goban Spur. Bathymetry on inset in meters.

Abundance estimates and stratigraphic occurrences of planktonic foraminiferal species are charted on Figures 2 through 6. Estimates of relative abundance, expressed as a proportion of the total planktonic foraminiferal assemblage, are based on specimen counts (approximately 150 per sample) using a tray provided with a grid. Results were tabulated in four categories:

1. Rare, less than $3 \%$

2. Few, 3 to $15 \%$

3. Common, 15 to $30 \%$

4. Abundant, more than $30 \%$

The total abundance of planktonic foraminifers (all species combined) relative to other constituents, both biotic and inorganic, was estimated in a similar way (Figs. 2-6). The abundance of other selected constituents and an assessment of preservation for planktonic foraminifers have also been charted on these figures. Abbreviated sample designations follow standard DSDP convention.

Planktonic foraminiferal assemblages have been interpreted in terms of the zonal schemes of Blow (1969) and Berggren and Van Couvering (1974) to expedite comparisons with previous biostratigraphic studies from other geographic areas. This chapter mentions only those species that are either numerically predominant through long time intervals or stratigraphically restricted enough to be useful even when rare. Quaternary and Neogene species have not been illustrated, because all have been figured in many previous reports. Poore (1979) is a par- ticularly useful reference because (1) it is a thorough treatment of high-latitude species from the North Atlantic, and (2) we have made direct comparisons with his hypotype material deposited at the U.S. National Museum, thus ensuring taxonomic uniformity with species that he has illustrated. Species that we used to interpret the Paleogene section are illustrated in Plates 1 through 11. Representatives of these species from the North Atlantic have not been so extensively figured in previous reports. Also, there is less agreement about the proper generic and species names that should be applied to many of these forms. For example, Truncorotaloides collactea (Finlay) of this report has been placed in the genera Globorotalia and Acarinina by other authors (Bolli, 1957; Stainforth et al., 1975; Krasheninnikov, 1979). It has also been identified as several different species: G. spinuloinflata (Bandy) by Bolli (1957); A. rotundimarginata Subbotina by Krasheninnikov (1979). We follow Berggren (1977) in both generic and specific assignments, but species such as $T$. collactea require illustration to convey taxonomic concepts quickly and efficiently to a broad spectrum of scientists.

Leg 80 sites lie at nearly $50^{\circ} \mathrm{N}$ latitude, whereas the species used to define planktonic foraminiferal zones are largely tropical-subtropical forms. Consequently, most zonal boundaries presented in this chapter are approximated by using secondary indicator species. Any boundary based on primary indicator species is termed "defined" in this text, as opposed to "approximated." 


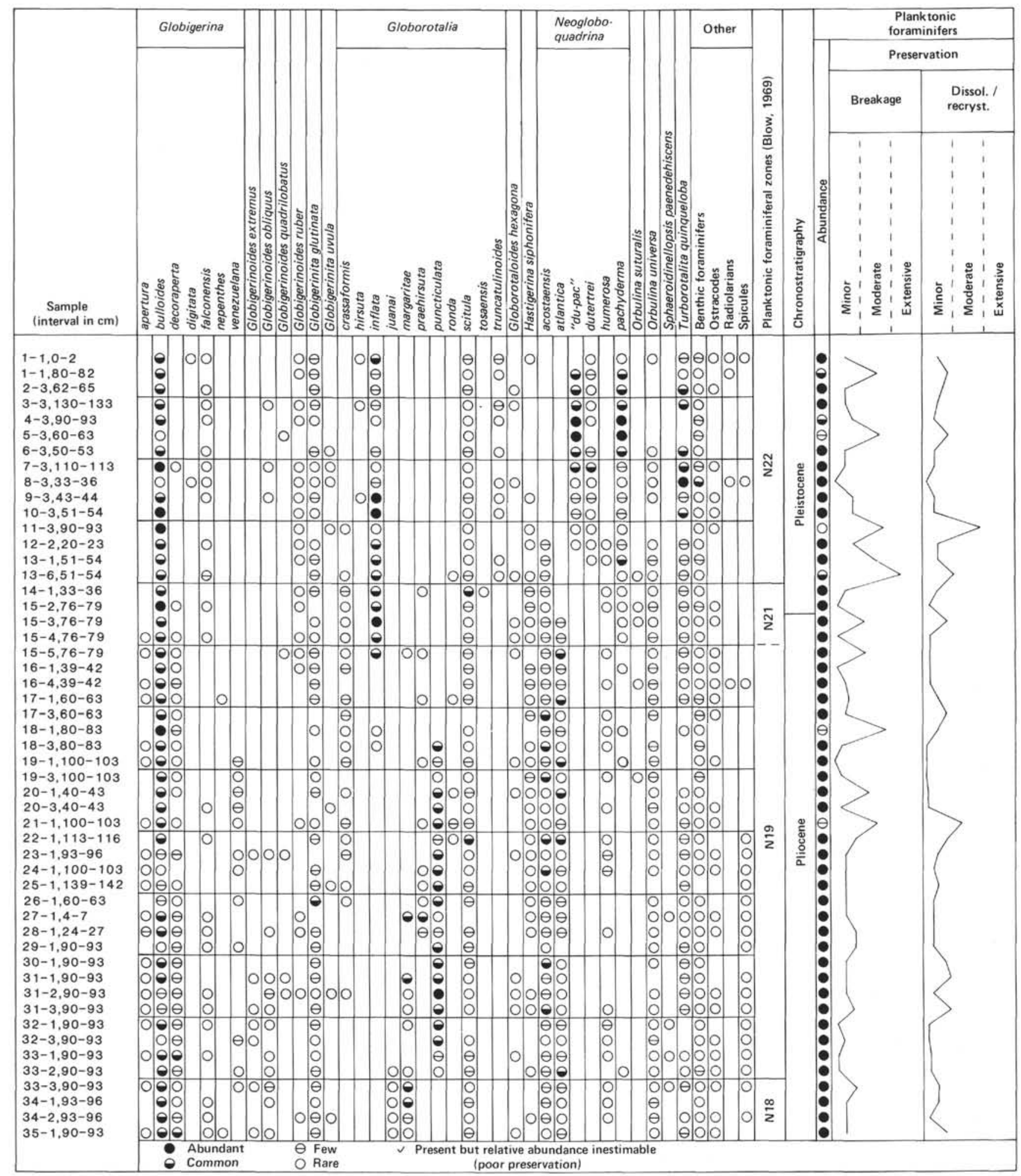

Figure 2. Occurrence of planktonic foraminifers and other selected constituents in samples from Hole 548 .

\section{STRATIGRAPHY OF CENOZOIC SEDIMENTS AT THE SITES}

\section{Site 548}

Site 548 , located in $1256 \mathrm{~m}$ of water, lies near the crest of a tilted Hercynian basement block that forms the boundary between sediment-filled half-grabens (Fig.
1). Two holes penetrated $556.5 \mathrm{~m}$ of sediment, $471 \mathrm{~m}$ of which is Cenozoic (Fig. 7).

\section{Hole 548}

We used a variable-length hydraulic piston coring system, and $93 \%$ of a $211-\mathrm{m}$ sequence of nannofossil and 


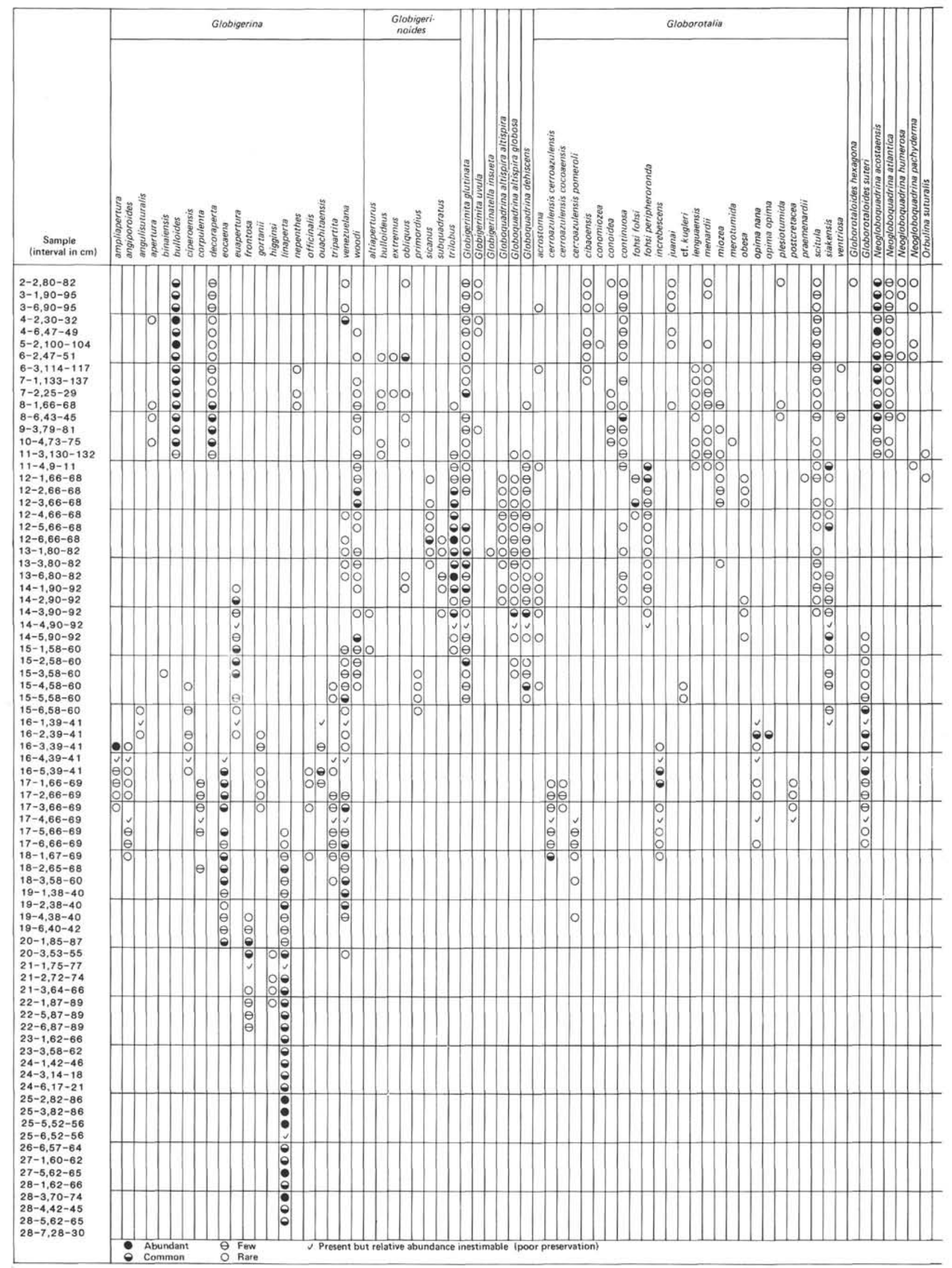

Figure 3. Occurrence of planktonic foraminifers and other selected constituents in samples from Hole 548A. 
CENOZOIC PLANKTONIC FORAMINIFERAL BIOSTRATIGRAPHY

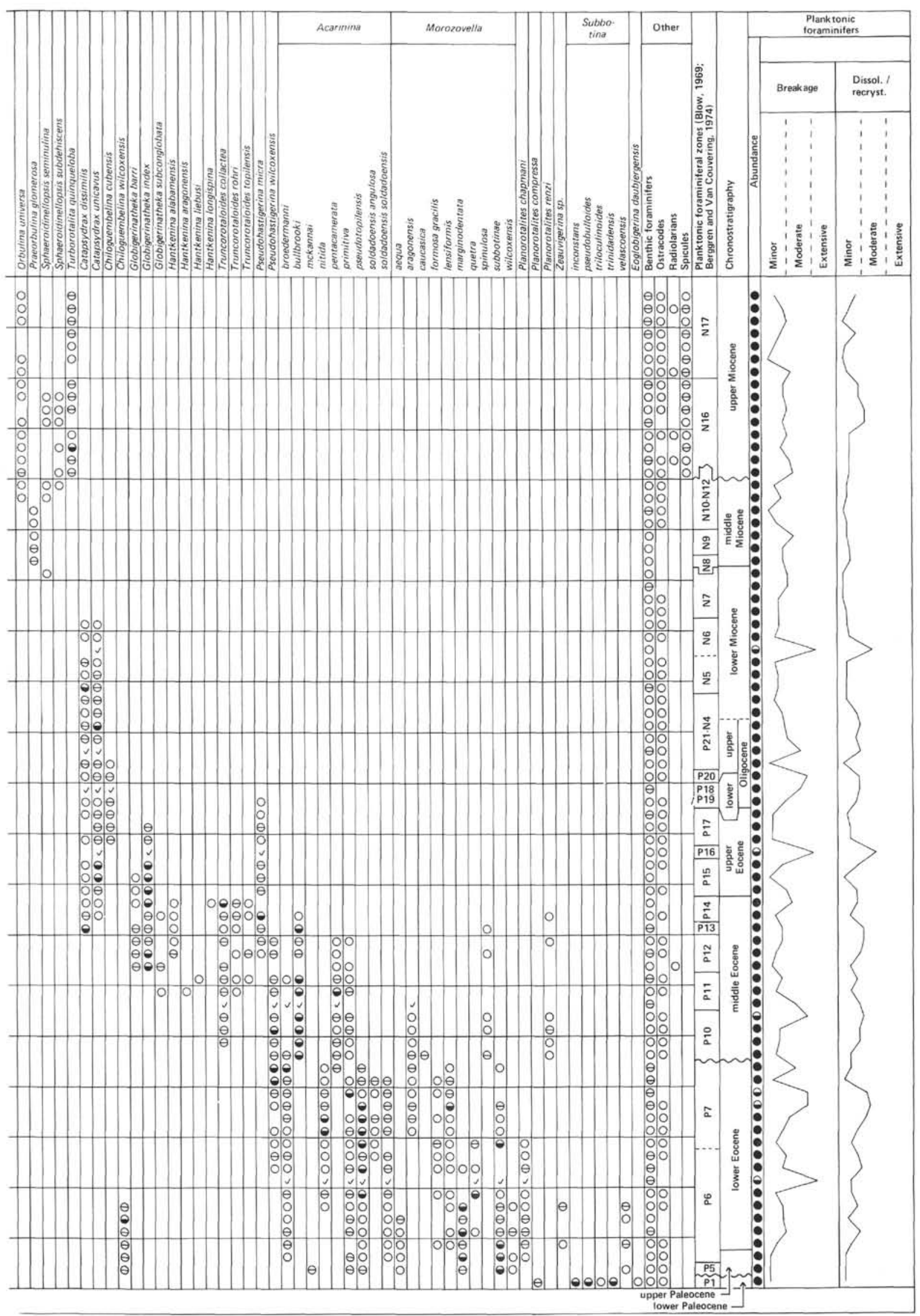

Figure 3. (Continued). 


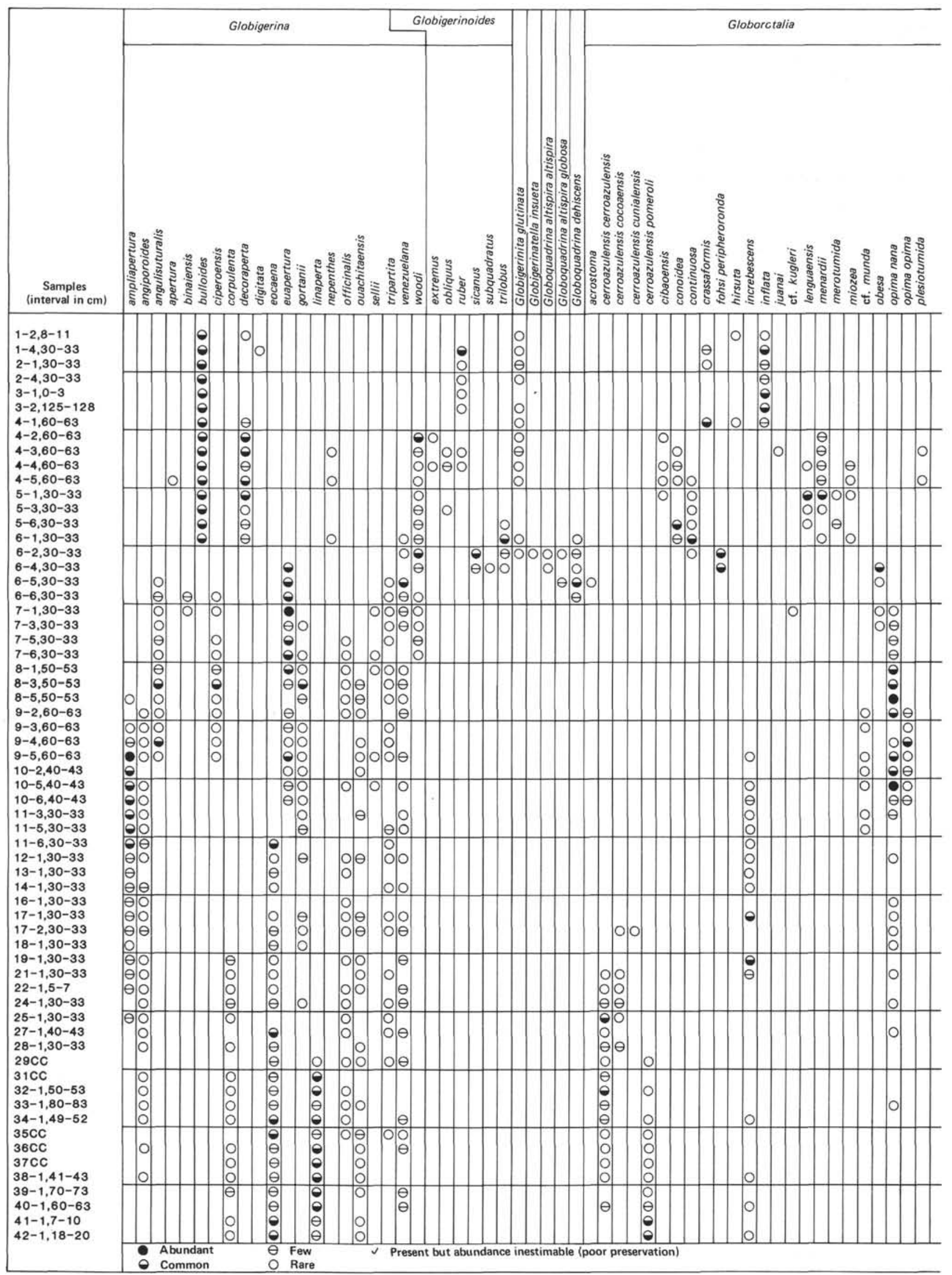

Figure 4. Occurrence of planktonic foraminifers and other selected constituents in samples from Hole 549A. 


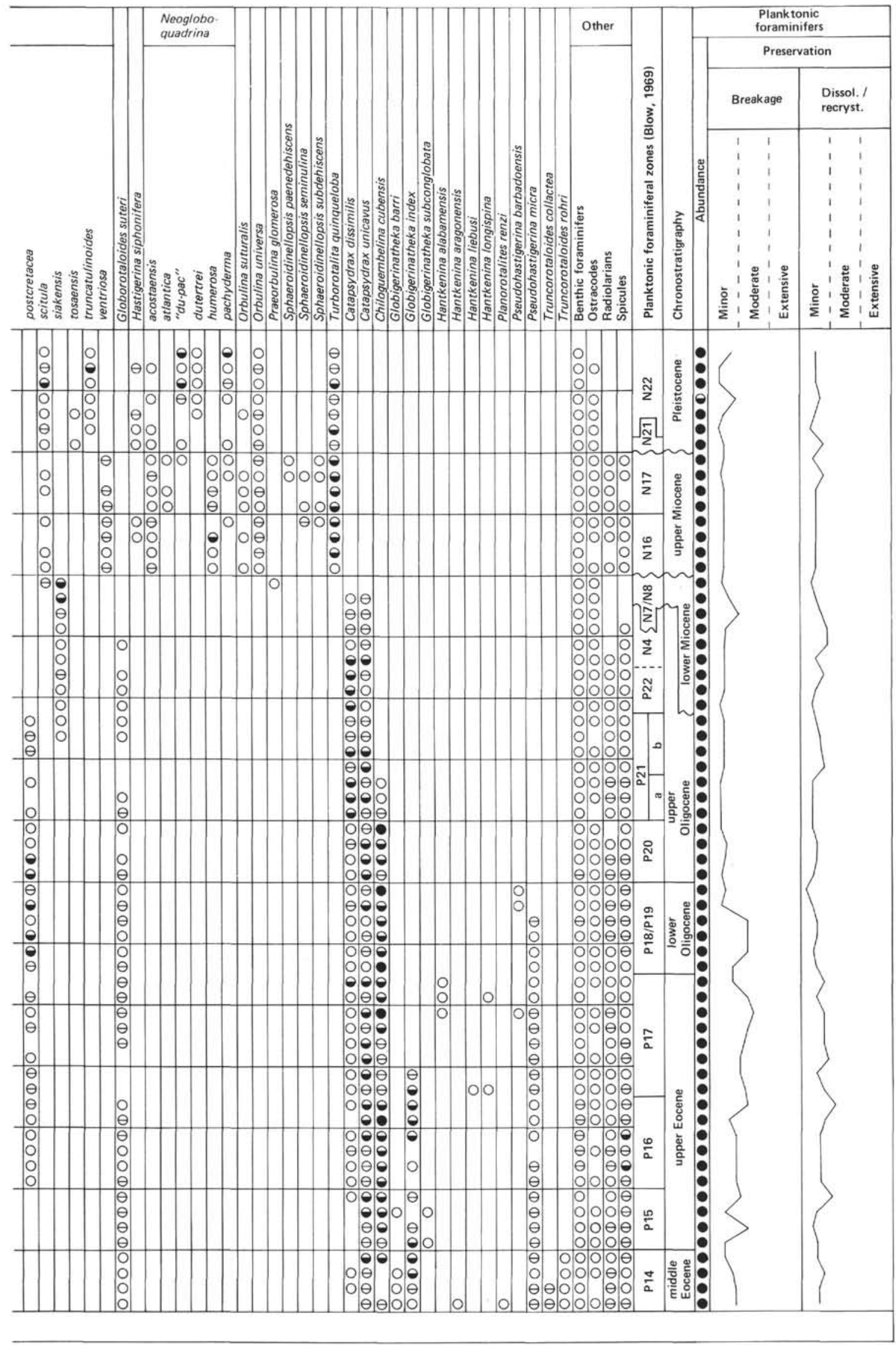

Figure 4. (Continued). 


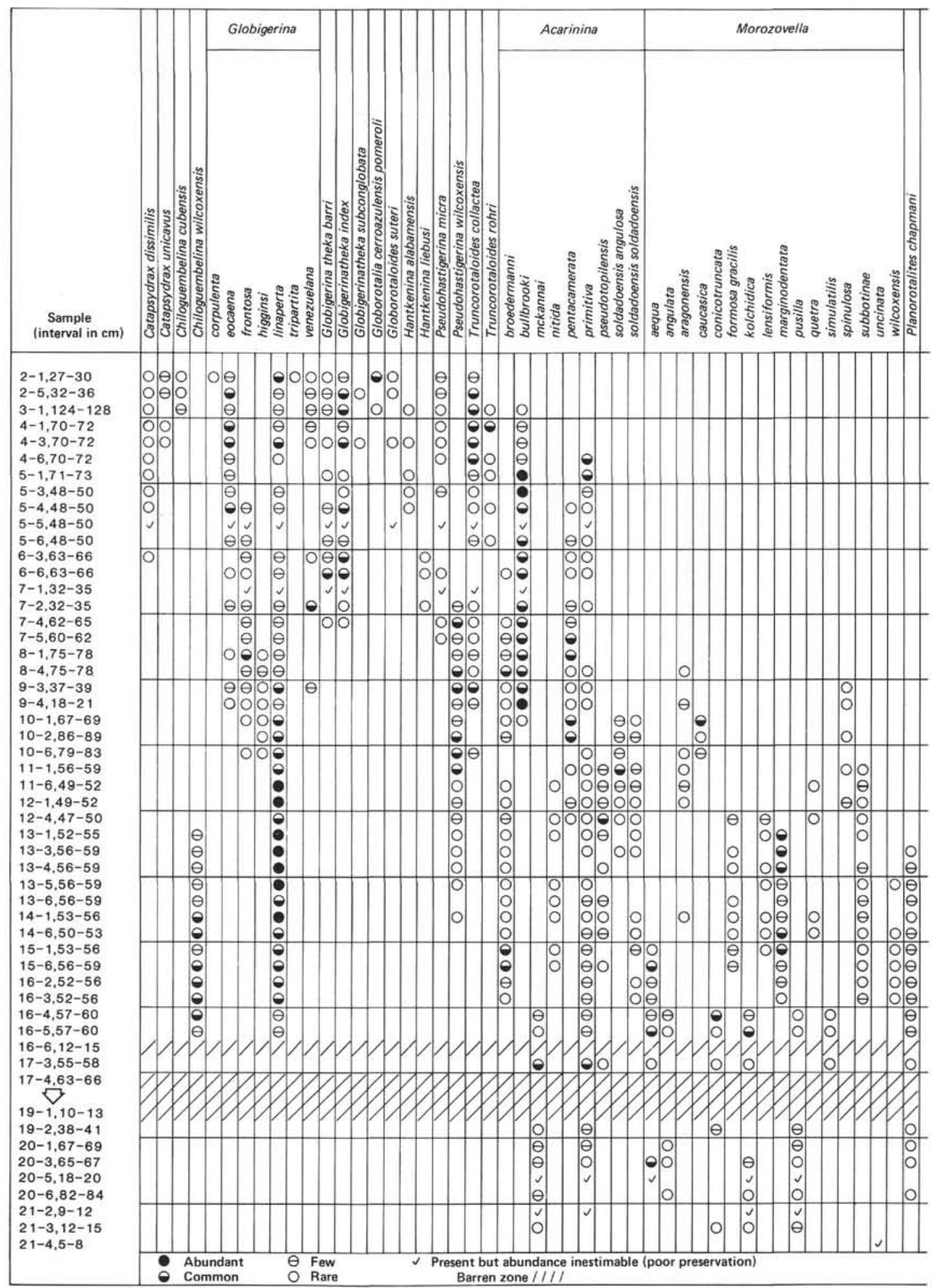

Figure 5. Occurrence of planktonic foraminifers and other selected constituents in samples from Hole 549.

marly nannofossil oozes was recovered. The oldest sediments cored are early Pliocene.

The Pliocene section is approximately $108 \mathrm{~m}$ thick, extending from Sample 548-35-1, 90-93 cm upward through Sample 548-15-3, 76-79 cm (Fig. 2). Except in six widely separated samples, planktonic foraminifers are abundant and very well preserved. Benthic foramini- fers are rare to few but consistently present; ostracodes are rare and occur sporadically; and spicules occur only in the lower portion of the Pliocene section.

The boundary between Zones N18 and N19, approximated by the first-appearance datum (FAD) of Globorotalia puncticulata and the last-appearance datum (LAD) of Globorotalia juanai, lies between Samples 548-33-3, 


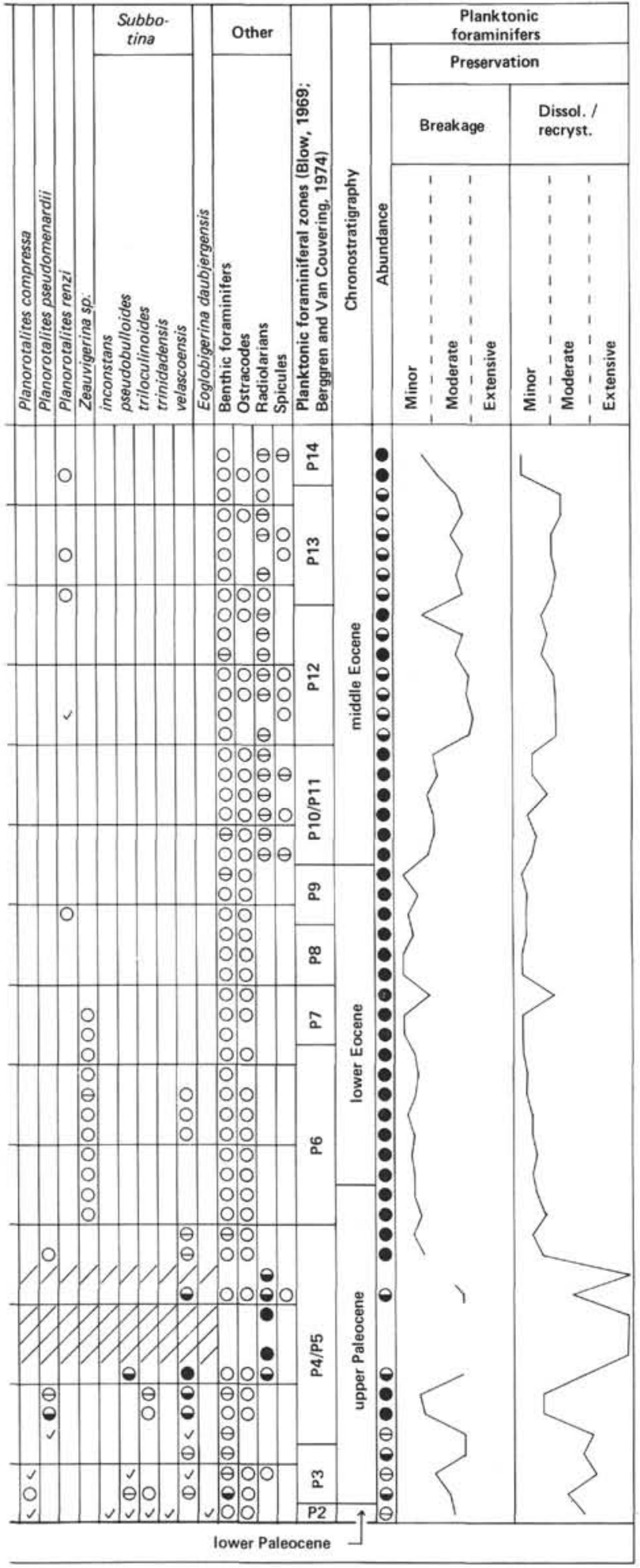

Figure 5. (Continued).

90-93 cm and 548-33-2, 90-93 cm. The lower portion of Zone N19 is characterized by the co-occurrence of Globorotalia puncticulata and $G$. margaritae. The upper portion of this zone is differentiated on the basis of the FAD of Globorotalia inflata and the corresponding LAD of $G$. puncticulata. Species that commonly and consistently occur throughout the Pliocene include Globigerina bulloides, Globigerinita glutinata, Globorotalia scitula, Neogloboquadrina atlantica, and N. acostaensis.

Planktonic foraminiferal assemblages indicate a subtle climatic change through the Pliocene. The species composition of lower Pliocene assemblages suggests warm temperate conditions. Warmer-water indicator species include the keeled Globorotalia margaritae and G. juanai, plus rare but consistently present specimens of Globigerinoides. The relative abundance of Globigerina bulloides, a reliable indicator of cool-water masses (Bé, 1959; Cifelli and Smith, 1970), is generally less than in the upper Pliocene. Upper Pliocene assemblages suggest cooler waters because warm-water indicators are absent, and Globigerina bulloides and Globorotalia inflata are more abundant. A decrease in the number of species upward through the Pliocene section is consistent with this interpretation.

The Pliocene/Pleistocene boundary, if defined by the Globorotalia tosaensis-G. truncatulinoides transition, appears to lie between Samples 548-14-1, 33-36 cm and 548-13-6, 51-54 cm. This does not coincide, however, with the nannofossil base-of-Pleistocene, which correlates more closely with paleomagnetic evidence. Both of the species just mentioned are rare at this latitude, and they occur only sporadically throughout their respective stratigraphic ranges. Thus, the true FAD of $G$. truncatulinoides may not have been observed, and the boundary may lie lower in the stratigraphic section. An alternative approach in high-latitude regions is to base the boundary on the LAD of Neogloboquadrina atlantica (Berggren, 1972). Use of this datum in Hole 548 brings the planktonic foraminiferal base-of-Pleistocene into agreement with both nannofossil and paleomagnetic evidence. The LAD of $N$. atlantica occurs in Sample 548-15-3, 76-79 cm.

The Pleistocene section, which is $102 \mathrm{~m}$ thick (Sections 548-15-2 through 548-1-1), is characterized by alternation of distinctly different assemblages that reflect major climatic fluctuations. Interglacial faunas have a greater number of planktonic species, are typified by the rarity of benthic foraminifers, and usually have an abundance of specimens of Globigerina bulloides and Globorotalia inflata. Warmer-water forms such as Hastigerina siphonifera and Orbulina spp. are present in modest numbers. Predominant species of the intervening glacial faunas are Neogloboquadrina pachyderma and $N$. " $d u$-pac", an intergradational form between $N$. $d u$ tertrei and N. pachyderma (Poore, 1979, p. 472). Glacial faunas have fewer planktonic species and a higher percentage of benthic foraminiferal specimens. Cooltemperate species like Globigerina bulloides and Globorotalia inflata persist but are less abundant; warmerwater species disappear. Some samples from glacial intervals (548-4-3, 90-93 cm; 548-5-3, 60-63 cm) contain sublittoral benthic species belonging to genera such as Quinqueloculina, Elphidium, and Buccella. Their presence indicates faunal mixing caused by downslope transport.

The faunal changes in the Pleistocene section correlate with variations in sediment type. Cold-water assem- 
S. W. SNYDER, V. J. WATERS

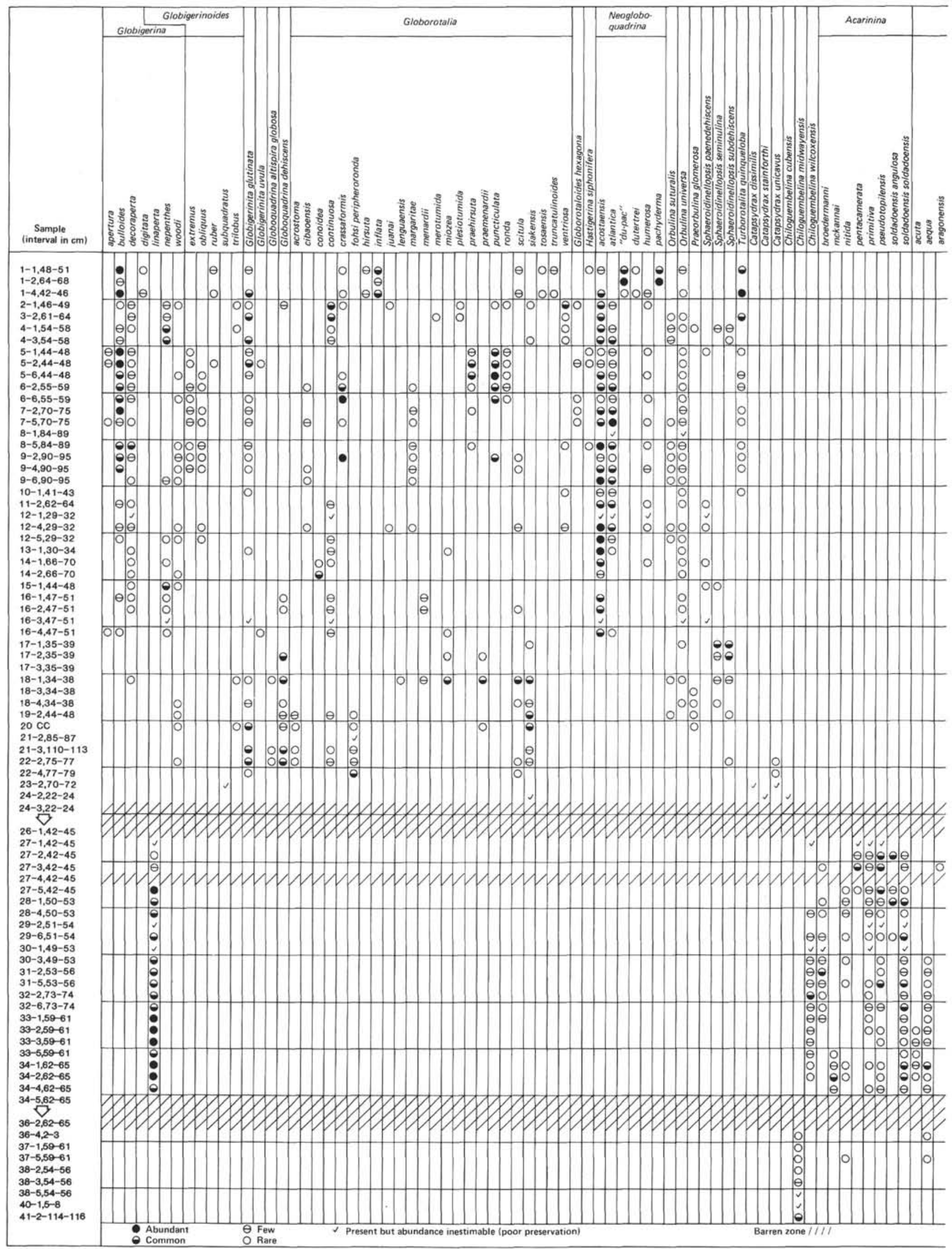

Figure 6. Occurrence of planktonic foraminifers and other selected constituents in samples from Hole 550. 


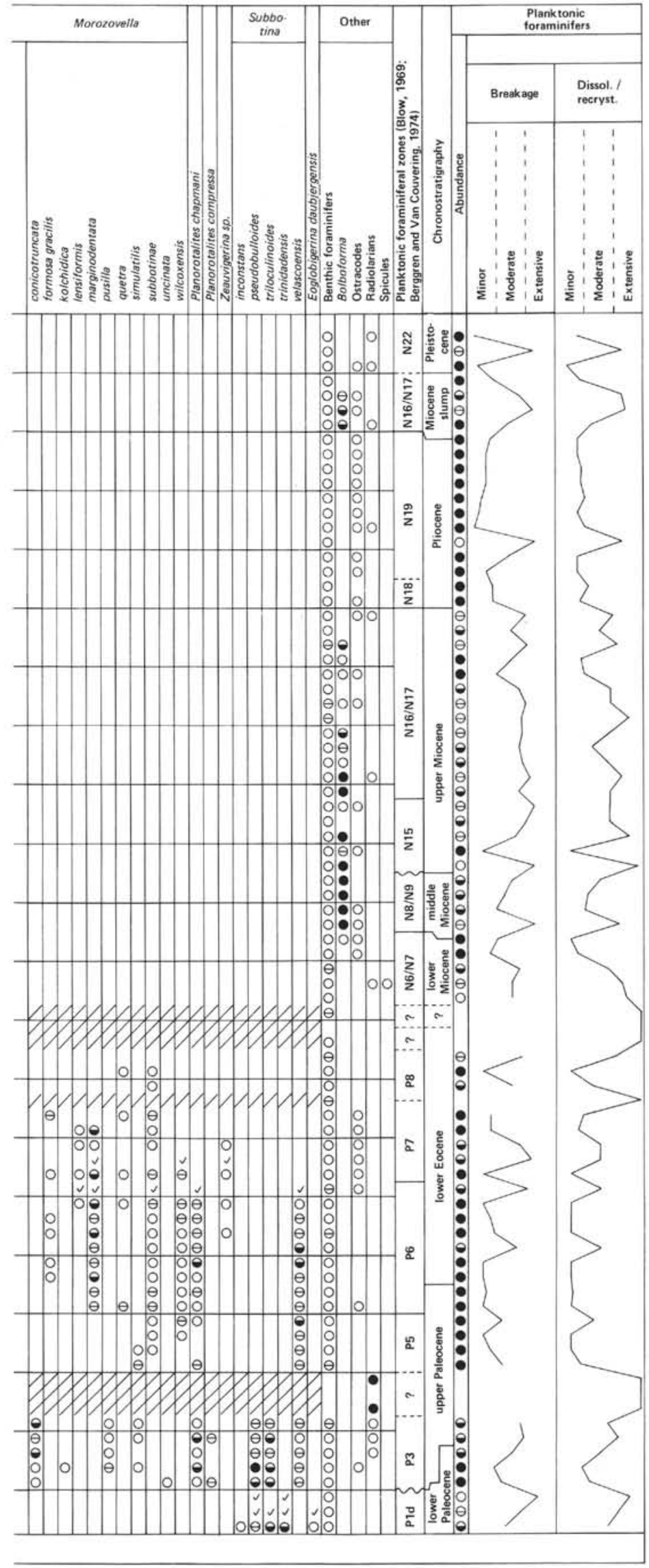

Figure 6. (Continued). 


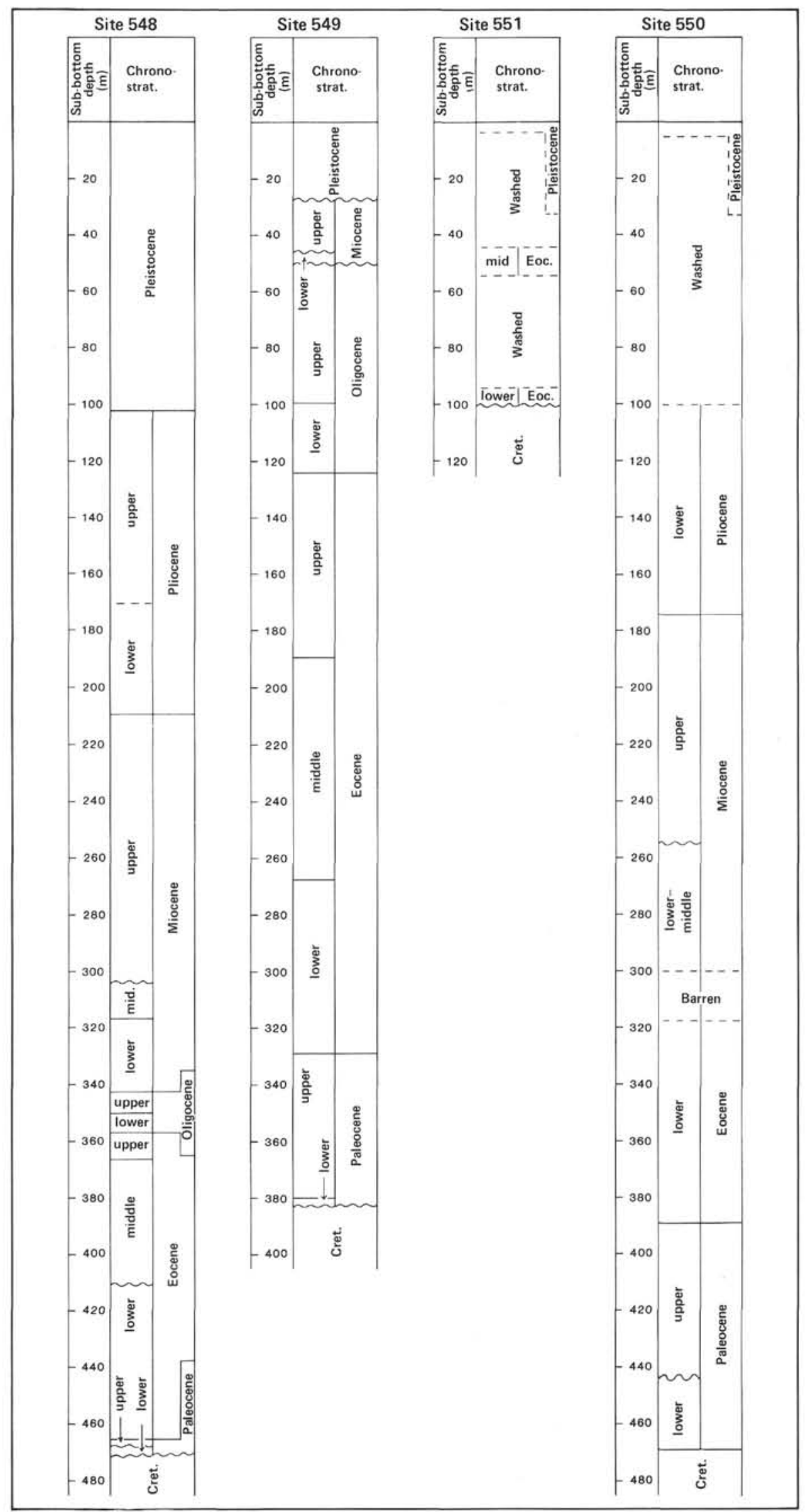

Figure 7. Chronostratigraphy and stratigraphic thickness of Cenozoic sediments at Leg 80 drill sites. 
blages are associated with an influx of detrital sediments, mostly quartz with trace amounts of glauconite and mica. More temperate-water assemblages are associated with sediments that lack the detrital components.

Preservation is good, and planktonic foraminifers are abundant throughout Hole 548. Moderate amounts of breakage and dissolution are, at least in part, associated with the influx of cold water-masses during the Pleistocene. Similar preservational episodes represented in two Pliocene samples are more difficult to explain. Generalized paleoclimatic interpretations are dependable, however, because preservational modification of assemblages has been minimal. Except for several glacial assemblages, neither is there any evidence of significant downslope faunal mixing.

\section{Hole 548A}

The standard DSDP rotary coring assembly was used for Hole 548A. Although the core recovery rate was not as high as in Hole 548, there are no major gaps in sample coverage within the Cenozoic section. This hole penetrated $256 \mathrm{~m}$ of nannofossil oozes, foraminiferal-nannofossil chalks, and marly nannofossil chalks ranging from lower Paleocene to upper Miocene (Fig. 3).

The oldest Cenozoic sediments recovered are middle Danian (Zone P1d). The faunal assemblage indicative of this zone occurs only in Sample 548A-28-7, 28-30 cm; and it includes Subbotina inconstans, S. pseudobulloides, S. triloculinoides, S. trinidadensis, and Eoglobigerina daubjergensis. Predominant species of this lowdiversity fauna belong to the genus Subbotina. Sediments of Zone Pld are separated from underlying Cretaceous sediments by an unconformity in which the lower Danian (Zones P1a-P1c) is missing. A hiatus spanning the upper Danian and most of the Thanetian occurs immediately above Sample 548A-28-7, 28-30 cm. A single sample (548A-28-5, 62-65 cm) is assigned to Zone P5 (upper Thanetian) because, in addition to several species of Morozovella and Acarinina that first occur in the upper Paleocene, it also contains significant numbers of Acarinina mckannai, the LAD of which is in the upper Paleocene. The lower portion of Zone P6 has a similar fauna, ericept that $A$. mckannai is not present. The Paleocene/Eocene boundary lies between Samples 548A-28-4, 42-45 cm and 548A-28-3, 70-74 cm. It is approximated by the FAD of Morozovella formosa gracilis and the first common and consistent occurrence of Acarinina broedermanni. Planktonic foraminifers are abundant and well preserved throughout this thin Paleocene section. Benthic foraminifers and ostracodes are rare but consistently present.

Only a portion of the lower Eocene (Zones P6 and P7) is present, but it is 55 m thick. The fauna consists of a diverse assemblage of Acarinina spp., most importantly $A$. broedermanni, $A$. nitida, $A$. pseudotopilensis, $A$. soldadoensis angulosa, and $A$. soldadoensis soldadoensis. The $\mathrm{P} 6 / \mathrm{P} 7$ zonal boundary is tentatively placed between Samples 548A-25-3, 82-86 cm and 548A-25-2, $82-86 \mathrm{~cm}$, on the basis of the proximity of (1) the LAD of Planorotalites chapmani and (2) the FAD of Morozovella aragonensis. Morozovella formosa gracilis, $M$. len- siformis, and $M$. subbotinae characterize the lower Eocene section. The most abundant species throughout this interval is Globigerina linaperta, with several species of Acarinina ranking as secondary in importance. Planktonic assemblages at several horizons exhibit extensive breakage and moderate dissolution, but elsewhere specimens are abundant and preservation is moderate to good. Between Samples 548A-22-6, 87-89 cm and $548 \mathrm{~A}-22-5,87-89 \mathrm{~cm}$ a hiatus spans the upper part of the lower Eocene (Zones P8 and P9).

The middle Eocene section is complete but somewhat compressed (about $46 \mathrm{~m}$ thick). The species composition of middle Eocene planktonic assemblages is dramatically different from that of lower Eocene assemblages. Common and characteristic middle Eocene species include Acarinina bullbrooki, A. pentacamerata, Morozovella spinulosa, Globigerinatheka barri, Globigerina frontosa, and Truncorotaloides collactea. The basal middle Eocene sample (548A-22-5, 87-89 cm) contains Morozovella caucasica, which disappears at the P9/P10 zonal boundary (Stainforth et al., 1975). However, because this sample also contains several species that are reliable middle Eocene indicators, it has been interpreted as Zone P10. The P10/P11 boundary is difficult to recognize at all the Leg 80 sites. In Hole 548A it is approximated by the stratigraphic proximity of the FAD for Globigerinatheka subconglobata and for Globigerina eocaena. The $\mathrm{P} 11 / \mathrm{P} 12$ zonal boundary is approximated by the LAD of Acarinina broedermanni and the corresponding FAD of Globigerinatheka barri and of $G$. index. The base of Zone P13, which is recognized only in Sample 548A-19-1, 38-40 cm, is approximatec by the LADs of Acarinina primitiva and Pseudohastigerina wilcoxensis; its top is approximated by the LAD of $A$. bullbrooki and the FADs of Globigerina corpulenta and $G$. tripartita. The FAD of Catapsydrax dissimilis and that of $C$. unicavus correspond to the base and top of Zone P13, respectively. The upper boundary of Zone P14 (the middle/upper Eocene contact) is defined by the abrupt disappearance of primary indicator species of Truncorotaloides. The predominant species of the middle Eocene, listed in order of decreasing relative abundance, are Globigerina linaperta, Acarinina bullbrooki, Globigerina eocaena, and Globigerina frontosa. Except for Sample 548A-21-2, 72-74 cm, where there is moderate breakage, planktonic foraminifers are abundant and well preserved through the middle Eocene.

The upper Eocene section is complete but highly compressed, extending from Sample 548A-18-1, 67-69 cm through Sample 548A-17-1, 66-69 cm (a thickness of about $10 \mathrm{~m}$ ). Upper Eocene assemblages are readily recognized by the presence of the Globorotalia cerroazulensis group and by the association of Globorotalia increbescens, G. opima nana, and Globigerina angiporoides. The P15/P16 zonal boundary is approximated by the FAD of Globorotalia postcretacea, and the P16/ P17 boundary by the FAD of Globorotalia cerroazulensis cocoaensis. Three of the five subspecies of Globorotalia cerroazulensis recognized by Toumarkine and Bolli (1970) have been identified in Hole 548A. Predominant species in the upper Eocene section of this hole include 
Globigerina eocaena, Catapsydrax unicavus, and Globigerinatheka index. The Eocene/Oligocene boundary lies between Samples 548A-17-1, 66-69 cm and 548A-16-5, $39-41 \mathrm{~cm}$. Its location is defined by the LADs of Globorotalia cerroazulensis cerroazulensis and G. cerroazulensis cocoaensis, both primary indicators. Except for the single sample assigned to Zone P16, upper Eocene assemblages are well preserved.

The compressed Oligocene section extends only from Sample 548A-16-5, 39-41 cm through Sample 548A-15-5, $58-60 \mathrm{~cm}$. Zone P18/P19 is tentatively separated from P20 by the presence of Pseudohastigerina micra and Globigerina eocaena in samples from P18/P19. Globigerina ampliapertura, G. angiporoides, and Globorotalia increbescens all disappear at or near the top of Zone P20. Zones P21-N4 extend from Sample 548A-16-2, $39-41 \mathrm{~cm}$ upward through Sample 548A-15-3, 58-60 cm. These zones cannot be reliably separated on the basis of planktonic foraminifers; thus, the location of the Oligocene/Miocene boundary is somewhat tentative. It has been approximated by the FAD of Globoquadrina dehiscens. The most reliable biostratigraphic datum within this interval is the LAD of Chiloguembelina cubensis, which lies within Zone P21. Although physical evidence (Poag et al., this vol.) and nannofossils (Müller, this vol.) indicate the presence of a major middle Oligocene unconformity, planktonic foraminiferal evidence regarding this hiatus is equivocal. Catapsydrax unicavus, $C$. dissimilis, and Globorotaloides suteri are common throughout the entire Oligocene section. Oligocene planktonic assemblages are rich, but there is generally a moderate amount of breakage and some recrystallization.

The lower Miocene sequence is about $28 \mathrm{~m}$ thick. The approximate location of the N4/N5 zonal boundary is bracketed by the FAD of Globoquadrina altispira globosa and the LAD of Globigerinoides primordius. Zone N5 extends upward through Sample 548A-14-5, 90-92 cm, where the FADs of Globorotalia fohsi peripheroronda and Globigerinoides subquadratus approximate its upper limit. The N6/N7 zonal boundary is defined by the LADs of Catapsydrax dissimilis and $C$. unicavus. The approximate top of Zone N7 lies immediately below the FAD of Praeorbulina glomerosa. Among the most abundant species in lower Miocene sediments are Globigerina euapertura, Globigerinoides trilobus, Globigerinita glutinata, Globorotalia siakensis, and species of Catapsydrax. Planktonic foraminifers are abundant and fairly well preserved in most samples.

Middle Miocene sediments occur from Sample 548A12-6, 66-68 cm upward through Sample 548A-11-4, $9-11 \mathrm{~cm}$, a thickness of approximately $13 \mathrm{~m}$. The slow sediment accumulation rates that produced such a compressed section make it difficult to differentiate reliably some of the planktonic foraminiferal zones. Species such as Praeorbulina glomerosa, Orbulina spp., and Globorotalia fohsi fohsi, which can be used to recognize zonal boundaries, are rare. The most abundant and commonly occurring species through this interval include Globigerina woodi, Globigerinoides trilobus, Globigerinita gluitinata, Globorotalia fohsi peripheroronda, and G. siakensis. The middle Miocene planktonic assemblages contain abundant and generally well preserved specimens.

Whereas Sample 548A-11-4, 9-11 cm contains a lower middle Miocene assemblage, Sample 548A-11-3, 130-132 $\mathrm{cm}$ contains an upper Miocene (Zone N16) fauna. Such numerically important species as Globigerina bulloides, G. decoraperta, and Neogloboquadrina acostaensis first occur immediately above the unconformity. The upper Miocene section is a sequence of turbidite deposits about $95 \mathrm{~m}$ thick. Planktonic foraminifers are generally abundant and well preserved, but species diversity is moderate, and relatively few reliable index species are present. Globigerina bulloides and Neogloboquadrina acostaensis are the predominant species throughout this interval. Species of secondary abundance include Globigerinita glutinata, Globorotalia continuosa, Globigerina decoraperta, and Neogloboquadrina atlantica. The N16/N17 zonal boundary, approximated by the LAD of Globorotalia lenguaensis, occurs between Samples 548A-6-3, 114-117 $\mathrm{cm}$ and 548A-6-2, 47-51 cm. Immediately below this boundary, in Sample 548A-7-1, 133$137 \mathrm{~cm}$, there is an abrupt change in the coiling direction of Neogloboquadrina acostaensis. Most specimens below this point coil sinistrally, and those above coil dextrally. Because $N$. acostaensis is so abundant, this change in coiling direction serves as an excellent stratigraphic marker. Sediments of Zone N17 are the youngest recovered from Hole 548A. The N16-N17 interval is the only portion of this hole with a significant siliceous faunal component. Spicules range from rare to few and occur in every sample. Radiolarians occur sporadically and are always rare.

\section{Site 549}

Site 549 is located in $2515 \mathrm{~m}$ of water near the landward edge of the Pendragon Escarpment (Fig. 1). Because this site is situated farther from the margin of its enclosing half-graben, there is a much thicker sedimentary sequence than at Site 548. However, the Cenozoic section at Site 549 is only 383 m thick, as compared with $471 \mathrm{~m}$ at Site 548 (Fig. 7).

\section{Hole 549A}

Hole 549A penetrated to a sub-bottom depth of 198.5 $\mathrm{m}$. Use of the variable-length hydraulic piston corer resulted in a core recovery rate of $74 \%$. Below $27 \mathrm{~m}$ of light brown-red calcareous muds and light gray marly foraminiferal nannofossil oozes, the sediments in the remainder of this hole are light green-gray to bluish white nannofossil chalks.

The oldest sediments cored lie within the middle Eocene, which extends from the bottom of the hole upward through Sample 549A-39-1, 70-73 cm (Fig. 4). These sediments contain a planktonic foraminiferal assemblage indicative of Zone P14. It is within this interval that Globorotalia cerroazulensis cerroazulensis first occurs. Truncorotaloides collactea and T. rohri occur here, disappearing at or near the top of this zone. Predominant species are Globigerina eocaena, $G$. linaperta, Globorotalia cerroazulensis pomeroli, Catapsydrax spp., 
and Globigerinatheka index. Middle Eocene planktonic foraminifers are abundant and well preserved, benthic foraminifers and ostracodes are rare, and radiolarians and spicules range from rare to few.

A thick upper Eocene section (about $67 \mathrm{~m}$ ) is present from Sample 549A-38-1, 41-43 cm through Sample 549A-17-2, 30-33 cm. The upper/middle Eocene (P14/ P15) boundary coincides with the LAD of the genus Truncorotaloides and the FAD of Globigerina angiporoides. Approximated by the FAD of Globorotalia postcretacea and the subjacent LADs of Globigerinatheka barri and G. subconglobata, the P15/P16 zonal boundary is placed between Samples 549A-34-1, 49-52 cm and 549A-35, CC. Zone P16 extends upward through Sample 549A-28-1, 30-33 cm, its boundary with Zone P17 approximated by the FAD of Globorotalia cerroazulensis cocoaensis, followed closely by the superjacent FAD of Globigerina ampliapertura. The Eocene/Oligocene boundary is placed between Samples 549A-17-2, 30-33 $\mathrm{cm}$ and $549 \mathrm{~A}-17-1,30-33 \mathrm{~cm}$. Although this placement does not agree with nannofossil evidence (see Snyder et al., this vol.), there are several lines of evidence that strongly support it. Hantkenina alabamensis last occurs in the several samples immediately below, and $H$. longispina is present in Sample 549A-18-1, 30-33 cm. Because the species of this Eocene genus are so extremely fragile, it is unlikely that their presence in these samples results from reworking. Also, the subspecies of Globorotalia cerroazulensis, interpreted as members of an evolutionary lineage by Toumarkine and Bolli (1970), terminate at Sample 549A-17-2, 30-33 cm. The stratigraphic distributions of subspecies recognized in Hole 549A agree well with the described evolutionary pattern. G. cerroazulensis pomeroli ranges from the bottom of the hole up to Sample 549A-29,CC. G. cerroazulensis cerroazulensis first occurs in Sample 549A-40-1, 60-63 cm and last occurs in Sample 549A-21-1, 30-33 cm. The FAD of $G$. cerroazulensis cocoaensis occurs in Sample 549A28-1, 30-33 cm; the LAD coincides with that of G. cerroazulensis cerroazulensis. G. cerroazulensis cunialensis, the most advanced member of the lineage, occurs only at the very top of the Eocene section. Its presence documents deposition during the very latest Eocene and, because the overlying section laid down in the early Oligocene appears to be complete, suggests continuous deposition across the Eocene/Oligocene boundary. Planktonic foraminifers throughout the upper Eocene section are abundant and moderately well preserved. Benthic foraminifers, ostracodes, and radiolarians are generally present but rare, whereas spicules occur somewhat more frequently in most samples. In the lower portion of Zone P16, however, benthic foraminifers and radiolarians are few, ostracodes are absent, and spicules become common. This increase in siliceous faunal elements relative to calcareous components is not reflected by any increase in dissolution/recrystallization.

The Oligocene section in Hole 549A is also thick (72 $\mathrm{m}$ ), but, based on physical evidence (Poag et al., this vol.) and nannofossils (Müller, this vol.), a major middle Oligocene hiatus exists at $97 \mathrm{~m}$ sub-bottom. Zone P18/P19 encompasses Samples 549A-17-1, 30-33 cm through 549A-11-6, 30-33 cm. The contact with Zone P20 is defined by the LAD of Pseudohastigerina barbadoensis. Globigerina angiporoides, interpreted by Stainforth et al. (1975) to range only into earliest Zone P20, appears to range higher in this section. Even though some of these higher occurrences could be due to reworking, the stratigraphic utility of its LAD is questionable. The P20/P21 zonal boundary lies immediately below Sample 549A-10-2, $40-43 \mathrm{~cm}$, within the stratigraphic overlap of Globorotalia increbescens and G. opima opima, and just below the FAD of Globigerina angulisuturalis. The LAD of Globigerina ampliapertura is thought nearly to coincide with this zonal boundary (Stainforth et al., 1975), but, like G. angiporoides, this species ranges significantly higher in Hole 549A. The P21/P22 zonal boundary (between Samples 549A-8-1, $50-53 \mathrm{~cm}$ and $549 \mathrm{~A}-8-3,50-53 \mathrm{~cm}$ ) coincides with the LAD of Globorotalia postcretacea and lies just above the LAD of the primary marker, G. opima opima. Zones P21a and P21b are separated on the basis of the LAD of Chiloguembelina cubensis. The boundary between Zones P22 and N4 lies immediately above Sample 549A-7-5, $30-33 \mathrm{~cm}$. It is approximated by the LAD of Globigerina officinalis, which is followed by the overlying LAD of Globorotalia opima nana. Zone N4 contains a typical upper Oligocene assemblage, which is replaced abruptly by a dramatically different fauna in Sample 549A-6-4, $30-33 \mathrm{~cm}$. Among the more abundant species within the Oligocene section are Globigerina ampliapertura, $G$. euapertura, Globorotalia opima nana, G. postcretacea, Catapsydrax dissimilis, C. unicavus, and Chiloguembelina cubensis, none of which crosses the overlying unconformity. The rare occurrence of several of these forms in the sample immediately above the unconformity is a result of reworking. Planktonic foraminifers are abundant and well preserved throughout the Oligocene. Benthic foraminifers, ostracodes, radiolarians, and spicules are present but rare in most samples.

Samples 549A-6-4, 30-33 cm and 549A-6-2, 30-33 cm contain an assemblage assignable to the Zone N7/N8 interval. The hiatus between this interval and the underlying Oligocene sediments spans most of the lower Miocene (upper part of N4-N6). Diagnostic species in this well-preserved lower Miocene assemblage include Praeorbulina glomerosa, Globigerinatella insueta, Globigerinoides sicanus, and Globorotalia fohsi peripheroronda. The siliceous faunal elements present lower in the section are absent in this interval. Rare specimens of Bolboforma in Sample 549A-6-2, 30-33 cm are probably contaminants from above. The entire lower Miocene section, which is overlain by yet another unconformity, is only several meters thick.

An upper Miocene (Zones N16-N17) sequence lies above sediments of the Zone N7/N8 interval. The base of Zone N16 is marked by the first occurrences of many species (including Globigerina bulloides, G. decoraperta, Globorotalia lenguaensis, and Neogloboquadrina acostaensis), most of which are common and conspicuous members of upper Miocene faunas. The N16/N17 zonal boundary is approximated by the last common occurrence of Globorotalia lenguaensis. Sphaeroidinellop- 
sis paenedehiscens first occurs shortly thereafter, and Globorotalia cibaoensis is consistently present only in Zone N17. Either portions of the upper Miocene are missing, or this interval is significantly more compressed than the same interval at Site 548. The N16/N17 zonal boundary lies between Samples 549A-5-1, 30-33 cm and $549 \mathrm{~A}-4-5,60-63 \mathrm{~cm}$. Thus, Zone N17 is unusually thin, suggesting that a portion of it may be missing. The stratigraphic ranges of those species present in the uppermost sample of this Miocene section do not conclusively document any missing section, however. A few specimens of Bolboforma occur in Sample 549A-4-2, $60-63 \mathrm{~cm}$, but this group is unimportant through the remainder of this interval. Other calcareous and siliceous faunal elements are generally present but rare.

Upsection from Sample 549A-4-1, 60-63 cm is a 27-m interval of Pleistocene sediments. It is separated from the underlying upper Miocene by an unconformity spanning the entire Pliocene. Assemblages from this abbreviated section, which includes portions of Zones N21 and N22, are not typically glacial or interglacial in aspect. Numerical predominance is almost equally shared among Globigerina bulloides, Globorotalia inflata, Neogloboquadrina pachyderma, and N. "du-pac." The excellent preservation and general lack of detrital quartz in these samples suggest closer affinities with the interglacial intervals recognized at Site 548. The Pleistocene section at Site 549 represents a condensed, possibly incomplete sequence of glacial and interglacial deposits. The apparent FAD of Globorotalia truncatulinoides and its zone of co-occurrence with $G$. tosaensis are in the lower part of the section. For reasons outlined in the discussion of Site 548, however, this datum is not interpreted as the base of the Pleistocene. Because Neogloboquadrina atlantica does not appear in sediments above the underlying unconformity, no Pliocene sediments have been recognized, and the precise location of the basal Pleistocene cannot be determined.

\section{Hole 549}

The standard rotary drilling system used in Hole 549 resulted in only a $46 \%$ core recovery rate. The poorest recovery was in portions of the Mesozoic section, however, and there are no large gaps in the coverage for Cenozoic sediments. Major lithologic units in the Cenozoic section include various colors of nannofossils chalks and marly nannofossil chalks which are Paleocene to middle Eocene.

The oldest Cenozoic sediments in Hole 549 are lower Paleocene (Zone P2) nannofossil chalks which unconformably overlie the Cretaceous (Fig. 5). Zone P2 is represented by a thin layer of sediment noted only in Sample $549-21-4,5-8 \mathrm{~cm}$. This zonal assignment is based on the concurrent-range zone of Morozovella uncinata, Subbotina triloculinoides, $S$. inconstans, S., pseudobulloides, and Planorotalites compressa.

Upper Paleocene sediments extend from Sample 54921-3, 12-15 cm through Sample 549-16-2, 52-56 cm, a thickness of nearly $50 \mathrm{~m}$. Zones P2 and P3 are provisionally differentiated because Subbotina inconstans is restricted to $\mathrm{P} 2$, whereas $S$. velascoensis does not ap- pear until P3. The P3/P4 zonal boundary coincides with the FADs of Morozovella aequa and Planorotalites pseudomenardii; the latter is a primary indicator of Zone P4. The remainder of the upper Paleocene section is more difficult to subdivide. Zones P4 and P5 cannot be reliably differentiated. The basal boundary of Zone P6 is approximated by the FADs of Morozovella marginodentata, $M$. subbotinae, and $M$. wilcoxensis. Slightly higher in the section, the FAD of Morozovella formosa gracilis approximates the Paleocene/Eocene boundary. Planktonic foraminifers are uncommon and rather poorly preserved throughout much of the Paleocene. In the middle and upper portions of the Zone P4/P5 interval are zones barren of calcareous microfossils. Radiolarians become abundant in these horizons. Benthic foraminifers range from few to common in the lowermost and uppermost portions of the Paleocene.

Conformably overlying Paleocene sediments is a lower Eocene section extending upward through Sample 549$10-1,67-69 \mathrm{~cm}$, a thickness of nearly $65 \mathrm{~m}$. The P6/P7 zonal boundary has been approximated on the basis of the LAD of Planorotalites chapmani and the corresponding FAD of Acarinina soldadoensis angulosa. The LADs of Morozovella formosa gracilis and $M$. lensiformis serve as the main evidence for approximating the P7/P8 zonal boundary. The LAD of $M$. marginodentata occurs slightly below this boundary. The P8/P9 boundary is defined by the FADs of Globigerina frontosa and Morozovella caucasica. The LAD of Morozovella subbotinae and that of Acarinina pseudotopilensis occur in the middle of Zone P8. The top of Zone P9 (the lower/middle Eocene boundary) is approximated by the LADs of Acarinina soldadoensis soldadoensis and $A$. soldadoensis angulosa. Acarinina bullbrooki first occurs at the base of Zone P10. Among the most abundant and commonly occurring species in the lower Eocene section are Chiloguembelina wilcoxensis, Globigerina linaperta, Pseudohastigerina wilcoxensis, Acarinina broedermanni, and Morozovella marginodentata. Planktonic foraminifers are abundant and well preserved throughout, benthic foraminifers and ostracodes rare but consistently present, and siliceous faunal elements significantly absent.

Middle Eocene sediments occur upward from Sample $549-9-4,18-21 \mathrm{~cm}$ to the top of Hole $549(72 \mathrm{~m})$. Zones P10 and P11 cannot be reliably differentiated, despite the abundance and good preservation that characterize planktonic assemblages in this interval. The last common occurrence of Acarinina broedermanni and the nearly simultaneous FADs of Globigerinatheka barri and $G$. index approximate the base of Zone P12. The boundary between Zones $\mathrm{P} 12$ and $\mathrm{P} 13$ is approximated by the LAD of Acarinina pentacamerata and the FAD of Hantkenina alabamensis. Catapsydrax dissimilis and C. unicavus occur just below and above this boundary, respectively. The LAD of Acarinina bullbrooki and the FAD of Chiloguembelina cubensis approximate the P13/P14 zonal boundary. Predominant species of the middle Eocene are Globigerina eocaena, G. frontosa, $G$. linaperta, Globigerinatheka index, Truncorotaloides collactea, and Acarinina bullbrooki. Unlike the Zone P10/ 
P11 interval, the remainder of the middle Eocene section is characterized by moderate to extensive breakage and moderate dissolution. Planktonic foraminifers are common, benthic foraminifers and ostracodes rare. In contrast to the lower Eocene, middle Eocene samples generally contain radiolarians, and spicules occur rarely and sporadically.

\section{Site $\mathbf{5 5 0}$}

Site 550 is on the Porcupine Abyssal Plain in a water depth of $4420 \mathrm{~m}$ (Fig. 1). Two holes penetrated $685 \mathrm{~m}$ of sediment lying above a basement complex composed of basalts interbedded with limestones. Approximately 469 $\mathrm{m}$ of this sedimentary section is Cenozoic (Fig. 7). Continuous coring was initiated at a depth of $100 \mathrm{~m}$ subbottom.

\section{Hole 550}

Standard rotary coring procedures resulted in recovery of $59 \%$ of the cored section. Recovery was much better than this average throughout most of the Cenozoic, where sediment types include nannofossil oozes and chalk, marly nannofossil chalk, and mudstone.

The oldest sediments recovered from Hole 550 are lower Paleocene (Zone P1d). Along with several longerranging species, samples assignable to this zone contain Subbotina inconstans, S. trinidadensis, and Eoglobigerina daubjergensis. The lower Paleocene section, about $14 \mathrm{~m}$ thick in Hole 550, appears to overlie Cretaceous sediments unconformably; but lowermost Paleocene strata have been recognized at this site (see Hole 550B).

Upper Paleocene sediments are present from Sample 550-38-3, 54-56 cm upward through Sample 550-33-2, $59-61 \mathrm{~cm}$, a thickness of $49 \mathrm{~m}$. Species useful in distinguishing these sediments from those of the underlying Zone P1d include Planorotalites chapmani, Morozovella conicotruncata, $M$. pusilla, and $M$. simulatilis. There is no faunal evidence for the presence of Zone P2, so a hiatus is inferred between the upper and the lower $\mathrm{Pa}$ leocene. The 15-m interval spanning Samples 550-34-5, $62-65 \mathrm{~cm}$ through $550-36-2,62-65 \mathrm{~cm}$ is completely devoid of planktonic foraminifers. Below lie sediments of Zone P3, and above, those of P5. The occurrences of Acarinina soldadoensis soldadoensis and A. pseudotopilensis indicate Zone P5. The P5/P6 zonal boundary is approximated by the LAD of Acarinina mckannai and the FAD of Morozovella marginodentata. A short distance above, between Samples 550-33-2, 59-61 cm and 550-33-1, 59-61 cm, lies the Paleocene/Eocene boundary, which is approximated by the FADs of Acarinina broedermanni and Morozovella formosa gracilis. Longer-ranging, abundant species within the Paleocene are Chiloguembelina midwayensis, Morozovella aequa, Planorotalites chapmani, and Subbotina velascoensis. Planktonic foraminifers are common but rather poorly preserved below the barren zone, and abundant and well preserved above it. Benthic foraminifers are rare but consistently present, except within the barren zone, where radiolarians constitute the entire microfauna.

Lower Eocene sediments occur upward from Sample 550-33-1, 59-61 cm, through Sample 550-27-1, 42-45 cm.
Several samples in the lower portion of an overlying "barren zone" are tentatively included in the lower Eocene. These samples contain extremely rare, poorly preserved planktonic foraminifers, which are Eocene but which do not unequivocally indicate lower Eocene. The undoubted lower Eocene section, about $55 \mathrm{~m}$ thick, spans Zones P6 through P8. The P6/P7 zonal boundary lies between Samples 550-30-1, 49-53 cm and 550-29-6, $51-54 \mathrm{~cm}$. It is approximated by the LADs of Planorotalites chapmani and Subbotina velascoensis, and by the FAD of Acarinina soldadoensis angulosa. The LAD of Morozovella aequa and the FAD of $M$. lensiformis occur immediately below this boundary. Zone P7 extends upward through Sample 550-27-5, 42-45 cm. Several species known to disappear at or near the P7/P8 boundary (Stainforth et al., 1975) are still present in this sample. These include Acarinina nitida, Morozovella formosa gracilis, $M$. lensiformis, and $M$. marginodentata. The first common occurrence of Acarinina pentacamerata (indicative of Zone P8) is in Sample 550-27-3, $42-45 \mathrm{~cm}$, but Sample $550-27-4,42-45 \mathrm{~cm}$ is barren of planktonic foraminifers. The P7/P8 boundary is, therefore, impossible to place precisely. Sediments assignable to Zone P8 are present through Sample 550-27-1, 42-45 $\mathrm{cm}$. Numerically predominant species of the lower Eocene section include Globigerina linaperta, Chiloguembelina wilcoxensis, Acarinina primitiva, A. pseudotopilensis, A. soldadoensis soldadoensis, Morozovella marginodentata, Planorotalites chapmani, and Subbotina velascoensis. The preservation and abundance of planktonic foraminifers are highly variable through the lower Eocene (Fig. 6). Benthic foraminifers occur consistently but rarely, and ostracodes are present only in Zone P7.

Immediately above the lower Eocene lies a $17-\mathrm{m}$ interval largely devoid of planktonic foraminifers. A few specimens in its lower portion are Eocene indicators, but a zonal assignment is impossible. The remainder of the interval, although it contains a fairly diverse benthic foraminiferal fauna, lacks planktonic species. Nannofossil evidence suggests the presence of a compressed Oligocene section (Müller, this vol.), but planktonic foraminiferal evidence can neither support nor contradict this interpretation. A compressed section, one or more unconformities, or a combination of both, may be present.

Lower Miocene sediments have been identified in Samples 550-24-2, 22-24 cm through 550-21-3, 110-113 $\mathrm{cm}$. The N6/N7 zonal assignment for this interval is based on the concurrent-range zone of Catapsydrax unicavus and Globorotalia fohsi peripheroronda, with the LAD of the former occurring in the middle portion of this section. The lower Miocene is characterized by poor preservation and a scarcity of planktonic specimens. Middle Miocene sediments (Zone N8/N9) lie conformably above. The boundary between the N6/N7 and N8/ N9 intervals is approximated by the first occurrence of Praeorbulina glomerosa, a datum which is followed sequentially by the FADs of Orbulina suturalis and $O$. universa in the next two samples upsection. Planktonic assemblages throughout the N8/N9 interval are sparse and poorly preserved, owing primarily to the effects of 
solution. Microfossil assemblages are composed largely of Bolboforma. Auffret and Pastouret (1979) noted a similar pattern in the middle Miocene of the Armorican margin, where calcispheres become abundant.

Upper Miocene sediments unconformably overlie those of the middle Miocene, extending upward from Sample 550-18-3, 34-38 cm through Sample 550-10-1, 41-43 cm (a thickness of $79 \mathrm{~m}$ ). The interval from Sample 550$17-1,35-39 \mathrm{~cm}$ through Sample 550-18-3, 34-38 cm has been interpreted as Zone N15. It may represent either the lowermost upper Miocene or the uppermost middle Miocene. Because nannofossil evidence suggests that no middle Miocene is present (Müller, this vol.), we have interpreted this interval as upper Miocene (Fig. 6). However, specimens of middle Miocene indicator species Globorotalia praemenardii and $G$. siakensis are present in Sample $550-18-1,34-38 \mathrm{~cm}$. In either case, the hiatus between middle and upper (or uppermost middle) Miocene strata spans Zones N10 through N14. The N15/N16 zonal boundary is defined by the FADs of several species that are numerically abundant through the remainder of the upper Miocene (Globigerina bulloides, Neogloboquadrina acostaensis). Zones $\mathrm{N} 16$ and $\mathrm{N} 17$ cannot be reliably differentiated in Hole 550, largely because dissolution and breakage have reduced the number of planktonic specimens present, and those remaining are difficult to identify. Several thin horizons within the N16/N17 interval (Samples 550-12-1, 29-32 cm; 550-15-1, 44-48 cm; $550-16-3,47-51 \mathrm{~cm}$; 550-16-4, 47-51 cm), and within Zone N15 (Samples 550-17-3, 35-39 cm; 550-18-1, 34-38 $\mathrm{cm} ; 550-18-3,34-38 \mathrm{~cm}$ ) contain abundant specimens of Bolboforma. Such horizons are characterized by sparse, poorly preserved planktonic foraminiferal assemblages. Murray (1979) reported Bolboforma from Zone N17 (possibly ranging from N16 to N18) at DSDP Sites 403, 404 , and 406. It appears that the abundant occurrence of Bolboforma is a reliable stratigraphic indicator for middle and upper Miocene sediments in deep-sea deposits of the Biscay-Goban Spur region. Bolboforma cannot, however, be so used in shallower-water localities (Sites 548 and 549), because specimens are generally absent and rare when present.

Pliocene sediments containing well-preserved, moderately diverse assemblages extend upward from Sample 550-9-6, 90-95 cm through Sample 550-5-1, 44-48 cm. The Miocene/Pliocene boundary is approximated by the LAD of Globorotalia continuosa and the FAD of $G$. margaritae. The faunas suggest that mostly lower to middle Pliocene sediments are present (Zones N18-midN19). Globorotalia puncticulata, which ranges only through the middle Pliocene, is present in the uppermost sample of the Pliocene. The N18/N19 zonal boundary is tentatively placed at the FADs of Globorotalia crassaformis and G. puncticulata. Other species that typify Pliocene sediments include Globigerina apertura, Globorotalia praehirsuta, Globigerinoides extremus, Neogloboquadrina atlantica, and Sphaeroidinellopsis paenedehiscens. Except for Sample 550-8-1, 84-89 cm, where the sand-sized fraction is composed mostly of framboids of pyrite, Pliocene assemblages are rich and well preserved. Benthic foraminifers and ostracodes are rare but consistently present throughout.

From Core 550-4 through Core 550-2, a thickness of approximately $22 \mathrm{~m}$, planktonic foraminiferal faunas are again dominated by Miocene species. Faunal associations in Core 550-2 contain species indicative of Pliocene and younger sediments (e.g., Globorotalia crassaformis, $G$. puncticulata, and $G$. ronda), along with species that do not range beyond the end of the Miocene (Globorotalia continuosa, G. siakensis, Globoquadrina dehiscens). Samples from Cores 550-3 and 550-4 contain a more purely Miocene fauna. Specimens of Bolboforma range from few to common within these two cores. Assemblages throughout all three cores are poorly to moderately preserved owing to breakage and dissolution/recrystallization. This entire sedimentary sequence represents slumped material that has been introduced into the younger Pliocene section. Only its lower boundary has been observed, since the interval immediately above was washed rather than cored (Fig. 7). Therefore, the upper contact has been represented by a dashed line in Figure 6.

The next interval from which samples are available (Core 550-1) is the mudline core. Assemblages from Samples 550-1-1, 48-51 cm and 550-1-4, 42-46 cm contain an abundance of Globigerina bulloides and Globorotalia inflata; a few specimens of warmer-water species, such as Globigerinoides ruber and Orbulina universa, are present. Such faunas typify interglacial periods, and closely resemble the assemblage present in surface sediments, indicating deposition in similar environmental settings. Sample 550-1-2, 64-68 cm is more typical of assemblages from glacial intervals. Neogloboquadrina pachyderma and $N$. "du-pac" dominate the assemblage, and warm-water species are absent. In contrast to interglacial assemblages, planktonic foraminifers are sparse and poorly preserved. This sample also contains an abundance of detrital quartz, thus strengthening the interpretation of deposition during a glacial episode. Core 550-1 penetrated only $5.5 \mathrm{~m}$ below the sediment surface, but even in this limited interval significant faunal fluctuations occur.

\section{Hole 550B}

Hole 550B was drilled at a position 50 feet to the east of Hole 550. Continuous coring was initiated at $456 \mathrm{~m}$ sub-bottom, well above the sub-bottom depth of the Cretaceous/Paleocene boundary in Hole 550. This boundary was encountered at $469 \mathrm{~m}$ sub-bottom in both holes.

Lowermost Paleocene sediments, not recognized in Hole 550, are present in Hole 550B. The poor core recovery in the lower part of Hole 550 is probably responsible for this discrepancy.

Biostratigraphic interpretation of Cenozoic sediments in Hole 550B was hindered by the abundance of Cretaceous forms that are also present; in several samples they are among the most common and conspicuous faunal elements. Hsü et al. (1982, p. 255) discuss the possibility that Cretaceous taxa in the lowermost Tertiary may include the last representatives of species heading 
for extinction, or the reworked individuals of truly Cretaceous species. We have adopted the latter viewpoint in dealing with Cretaceous taxa within the Paleocene assemblages from Hole 550B.

Sample 550B-1,CC appears to lie at or near the P1/ P2 zonal boundary. Both Eoglobigerina daubjergensis, which becomes extinct at this boundary, and Morozovella uncinata, which first occurs there, are present. Chiloguembelina midwayensis is the numerically predominant species. Samples from Sections 1 through 3 of Core 550B-2 all contain Eoglobigerina eugubina, indicating Zone P1a. Thus, the Cretaceous/Paleocene boundary at Site 550 has been interpreted as conformable (Fig. 7). Cretaceous planktonic foraminifers are common in the lower two sections of Core 550B-2. Benthic foraminifers and ostracodes are rare throughout the Paleocene.

\section{Site $\mathbf{5 5 1}$}

Site 551 is located in $3887 \mathrm{~m}$ of water near the seaward edge of a "bench" at the base of the Pendragon Escarpment (Fig. 1). Cenozoic sediments cored at this site include marly ooze, calcareous mud, nannofossil ooze, and calcareous mudstone. Only three spot-cores were taken in Cenozoic sediments at this site.

\section{Hole 551}

Sample 551-1-1, 4-6 cm contains an assemblage of Holocene planktonic foraminifers which is moderately well preserved (minor recrystallization). The most abundant species are Globigerina bulloides, Globorotalia inflata, and G. truncatulinoides; those of secondary abundance include Neogloboquadrina pachyderma, Orbulina universa, Hastigerina siphonifera, Globorotalia scit$u l a$, and $G$. hirsuta. Except for the increased relative abundance of Neogloboquadrina pachyderma and a corresponding decrease in Globorotalia truncatulinoides, the Pleistocene assemblage from Sample 551-1,CC is similar to that from surface sediments. The minor faunal differences suggest that the sediments of Sample 551-1,CC, although deposited in slightly cooler waters than those of the Holocene, accumulated during an interglacial period with climatic conditions similar to those of today. Similarity in the generic compositions of benthic foraminiferal assemblages from these samples indicates similar depths of deposition.

Sample 551-H1,CC, taken at $52.6 \mathrm{~m}$ sub-bottom, has an abundant, moderately well preserved planktonic assemblage indicating the lower middle Eocene (Zone P10). Globigerina linaperta and $G$. eocaena, both long-ranging Eocene forms, are the predominant species. Less abundant but more stratigraphically restricted forms include Acarinina pseudotopilensis, A. pentacamerata, $A$. bullbrooki, Truncorotaloides collactea, and Planorotalites renzi.

Lower Eocene sediments, similar in general lithology and color to those of Sample 551-H1,CC, occur in Core 551-H2 (94.5-104 m sub-bottom). Sample 551-H2-5, $33-35 \mathrm{~cm}$ comes from the base of this lithic unit at a depth of $100.8 \mathrm{~m}$ sub-bottom. Again, Globigerina linaperta is the most abundant species; taxa of lesser abun- dance include Acarinina broedermanni, A. soldadoensis soldadoensis, A. primitiva, Morozovella aequa, $M$. wilcoxensis, $M$. subbotinae, and $M$. marginodentata. On the basis of the concurrent-range zone of these species, the assemblage is assigned to Zone P6 (lower Eocene). The rarity of benthic foraminifers in sediments from both washed cores suggests deposition in lower bathyal depths.

Sample 551-H2-5, 36-38 cm was taken from a thin (about $2 \mathrm{~cm}$ ), darker unit immediately below the previously described sample. This unit lies within the upper Paleocene, but the poor preservation of the fauna hinders precise zonal assignment. The sample contains the lower contact with white Cretaceous chalks, and many of the best-preserved specimens are Cretaceous species. Forms indigenous to the Paleocene unit include Pseudohastigerina wilcoxensis and Chiloguembelina midwayensis, both of which are common, and rare specimens of Subbotina triloculinoides, S. pseudobulloides, and Acarinina aff. A. primitiva. There is faunal mixing involving not only the Cretaceous but also portions of the lower and upper Paleocene. Species from the lower stratigraphic levels may be reworked; those from higher in the section could be contaminants. Benthic foraminifers are common, largely because planktonic specimens have been preferentially destroyed by dissolution. This Paleocene zone is too thin to show at the scale of Figure 7.

\section{SUMMARY AND COMPARISON OF STRATIGRAPHIC SECTIONS, LEG 80 SITES}

Comparison of Sites 548, 549, and 550 reveals both important similarities and prominent differences. Lack of continuous coring severely limits observations concerning Site 551, but a few general trends can be recognized. A brief series-by-series survey of all sites will facilitate more comprehensive statements to be made later (Fig. 7).

Paleocene sediments at Site 548 encompass only two planktonic foraminiferal zones, P1 being overlain unconformably by P5. Preservation is good through both zones. Site 549 has a more complete Paleocene section, which includes Zones P2, P3, and P4/P5. Moderate dissolution characterizes the lower two zones; extensive dissolution, the P4/P5 interval. Zones P4 and P5 cannot be differentiated, and this interval contains horizons barren of planktonic foraminifers. Although an unconformity cannot be documented, a mid-Paleocene event of some sort is suggested. Both an unconformity and a barren zone are present at Site 550. Zone P1d is unconformably overlain by P3, which is, in turn, separated from P5 by a barren zone. A very thin unit, tentatively assigned to the upper Paleocene, lies below the Eocene sediments at Site 551. Although zonal and series boundaries are difficult to interpret, a post-Cretaceous unconformity involving much of the Paleocene is present.

The Eocene section at Site 548 contains a large-scale unconformity separating the lower from the middle part of this series. The hiatus spans Zones P8 and P9. Preservation below the unconformity is generally good, but 
moderate dissolution is evident in several zones. The continuous middle and upper Eocene section contains abundant, well-preserved planktonic foraminifers. The Eocene section at Site 549 is thick, continuous, and characterized by well-preserved faunas, except through Zones P12 and $\mathrm{P} 13$, where there is moderate breakage and dissolution. Only the lower Eocene (Zones P6-P8) has been identified at Site 550. Preservation gradually deteriorates upsection until complete dissolution creates a barren zone, the lower portion of which contains Eocene forms too poorly preserved and too scarce to permit assignment to any specific zone. The Eocene at Site 551, like that at Site 549, is thick, accounting for at least one half of the Cenozoic section.

Site 548 has an apparently complete, although greatly compressed, Oligocene section. Nannofossil Zone NP23 is extremely compressed (Müller, this vol.), suggesting a major unconformity within it. In contrast, all identifiable planktonic foraminiferal zones appear to be rather uniformly compressed. The Oligocene section at Site 549 is thick, but physical evidence clearly indicates an unconformity. Nannofossil Zone NP23 is again unusually thin, but there is no conclusive foraminiferal evidence for an unconformity. No Oligocene planktonic foraminiferal assemblages are present at Site 550. Nannofossil evidence suggests, however, that an extremely compressed Oligocene section containing several unconformities lies within a zone barren of planktonic foraminifers. There is no way for us to evaluate the nannofossil-based interpretation.

The thick Miocene sequence at Site 548 contains an unconformity in which planktonic foraminiferal Zone N12 is overlain by Zone N16. This hiatus spans the upper half of the middle Miocene. The remainder of the Miocene is complete, and contains abundant, well-preserved assemblages. The thin Miocene section at Site 549 contains two unconformities, one spanning the middle Miocene and the other much of the lower Miocene. Those few Miocene foraminiferal zones present contain rich and well-preserved faunas. Most of the middle Miocene is also missing at Site 550, where Zone 15 lies immediately above the N8/N9 interval. Moderate breakage and moderate to extensive dissolution characterize Miocene assemblages from this site.

The Pliocene-Pleistocene section at Site 548 is very thick, and contains no unconformities that can be identified on the basis of planktonic foraminifers. Pliocene assemblages are well preserved, whereas those of the Pleistocene indicate climatic fluctuations, with warmerwater assemblages well preserved and glacial faunas poorly to moderately well preserved. At Site 549 the Pliocene is missing. A thin Pleistocene section with recognizable evidence of several climatic shifts unconformably overlies Miocene sediments. Only the mudline core is available from Quaternary sections at Sites 550 and 551. Several subtle climatic variations are recorded, but the thickness of Pleistocene and subjacent sediments cannot be determined, because the next cores downsection come from a much greater depth below the seafloor.
The most striking similarities among Leg 80 sites are the several stratigraphic gaps which, although they have hiatuses of varying duration, occur at approximately the same biostratigraphic level across the region. A middle Paleocene and a late middle to early late Miocene gap are well documented. Although nannofossil evidence suggests a gap in the middle Oligocene, planktonic foraminiferal evidence is lacking or inconclusive. Any hiatus that may exist is obscured, either by location within a foraminiferal zone or by complete dissolution of planktonic tests. Foraminiferal analyses do not preclude the presence of an unconformity, but neither do they demonstrate its existence. Each of these gaps corresponds in general to worldwide unconformities that have been related to global cycles of sea-level change during Cenozoic time (Vail et al., 1977, 1979). Because Leg 80 sites cross the modern continental slope and extend to abyssal depths, simple sea-level fluctuations could hardly have produced simultaneous breaks at each of them. The contrast in preservation between slope and abyssal sites suggests that differences in water depth have been significant at least since the early Neogene. Changes in bottom-water circulation and fluctuations in the carbonate compensation depth, perhaps associated with the tectonic movements of seafloor spreading, may have produced some of these gaps.

Perhaps more striking than the similarities among Leg 80 sites are the differences, both in the number and stratigraphic positions of unconformities and in the thicknesses of individual chronostratigraphic subdivisions (Fig. 7). The lower Eocene unconformity at Site 548 contrasts with the complete Eocene section at Site 549. At Site 550 only the lower Eocene is present, whereas the middle and upper Eocene sections at Sites 548 and 549 are continuous and complete. The lower Miocene unconformity at Site 549 contrasts with the complete section at Site 548 . The barren zone below the N6/N7 interval at Site 550 may or may not include lowermost Miocene sediments. Site 548 has a thick and continuous Pliocene section, but Site 549 lacks any sediments belonging to this series. Despite their geographic proximity to one another, the sites have obviously had distinct geologic histories. Each slope-site lies within a different half-graben located at a different position along the margin. Differences in depositional depth are partly responsible for variations in the stratigraphic record. The major reason for such differences, however, is that each site lies at a different position within its respective halfgraben. As evidenced by the seismic records, dramatic stratigraphic changes can occur across short lateral distances in the marginal portions of these structures.

\section{TAXONOMIC NOTES}

The subjective nature of determining generic limits is a problem usually solved by defining genera on the basis of one or a few morphological features. The resulting classification systems are simple and readily applied, but are often somewhat artificial. Fleischer (1974) argues that classification systems should be based upon reconstructed phylogeny rather than upon strict and inflexible 
morphological characters. There are uncertainties, however, in the reconstruction of many lineages, particularly among Paleogene species.

Contemporary workers have approached the generic classification of Paleogene species in two basic ways. One is to lump the vast majority of species into one or the other of two genera, Globigerina and Globorotalia (Stainforth et al., 1975). Because so many species belonging to diverse lineages are assigned to these two genera, some workers argue that they have become meaningless (Fleisher, 1974). The other basic approach is to subdivide Paleogene species into a number of genera defined (although not adequately, according to Stainforth et al., 1975) by a complex of morphological characters. We choose to follow this latter scheme, which was outlined by McGowran (1968) and modified and expanded by subsequent authors (Fleisher, 1974; Berggren, 1977).

The following is a brief description of generic concepts as they have been applied to Paleogene species in this chapter.

1. Acarinina is characterized by a pseudospinose wall, the lack of a distinct peripheral carina, and a test form that is usually broadly planoconvex or conicotruncate.

2. Eoglobigerina is used here to denote diminutive globigeriniform species that have somewhat variable wall structure and apertural characteristics. Although rather vaguely defined, this generic category does serve to distinguish primitive Paleocene forms from the Neogene genus Globigerina.

3. Morozovella has a pseudospinose surface texture and, more important, a peripheral carina formed by thickened pseudospines. The development of the carina is somewhat variable from species to species.

4. Planorotalites, with a smooth test surface, perforate wall, and later chambers that tend to be compressed, is easily distinguished from other Paleogene genera. The periphery ranges from imperforate to strongly keeled.

5. Subbotina is characterized by a non-hispid, reticulate surface ornamentation. Chambers are usually rounded and somewhat inflated.

6. Truncorotaloides has wall structure similar to that of Acarinina and Morozovella. It is non-carinate, and has typical acarininid test morphology, except that secondary dorsal sutural apertures are a persistent feature.

During this study, the process of identifying Cenozoic species was based on the examination of type specimens at the U.S. National Museum, holotype illustrations in the Catalogue of Foraminifera, and illustrations and descriptions in modern comprehensive works on planktonic foraminifers. Because the original reference for each species was not consulted, and because original citations to the species identified during this study are readily available in many recent publications, the remainder of the taxonomic section is reduced to an alphabetical listing of genera and their respective species.

\section{ACARININA}

\footnotetext{
A. broedermanni (Cushman and Bermudez)

A. bullbrooki (Bolli)

A. mckannai (White)

A. nitida (Martin)
}
A. pentacamerata (Subbotina)
A. primitiva (Finlay)
A. pseudotopilensis Subbotina
A. soldadoensis angulosa (Bolli)
A. soldadoensis soldadoensis (Brönnimann)
CATAPSYDRAX

C. dissimilis (Cushman and Bermudez)

C. stainforthi Bolli, Loeblich, and Tappan

C. unicavus Bolli, Loeblich, and Tappan

\section{CHILOGUEMBELINA}

C. cubensis (Palmer)

C. midwayensis (Cushman)

C. wilcoxensis (Cushman and Ponton)

\section{EOGLOBIGERINA}

E. daubjergensis (Brönnimann)

E. eugubina (Luterbacher and Premoli Silva)

GLOBIGERINA

G. ampliapertura Bolli

G. angiporoides Hornibrook

G. angulisuturalis Bolli

G. apertura Cushman

G. binaiensis Koch

G. bulloides d'Orbigny

G. ciperoensis Bolli

G. corpulenta Subbotina

G. decoraperta Takayanagi and Saito

G. digitata Brady

G. eocaena Gümbel

$G$. euapertura Jenkins

G. falconensis Blow

$G$. frontosa Subbotina

G. gortanii (Borsetti)

G. higginsi (Bolli)

G. linaperta Finlay

G. nepenthes Todd

$G$. officinalis Subbotina

G. ouachitaensis Howe and Wallace

G. sellii (Borsetti)

G. tripartita Koch

G. venezuelana Hedberg

$G$. woodi Jenkins

GLOBIGERINATELLA

G. insueta Cushman and Stainforth

GLOBIGERINATHEKA

G. barri Brönnimann

$G$. index (Finlay)

G. subconglobata (Shutskaya)

GLOBIGERINITA

G. glutinata (Egger)

G. uvula (Ehrenberg)

GLOBIGERINOIDES

G. altiaperturus Bolli

G. bulloideus Crescenti

G. extremus Bolli and Bermudez

G. obliquus Bolli

G. primordius Blow and Banner

G. quadrilobatus (d'Orbigny)

G. ruber (d'Orbigny)

G. sicanus de Stefani

G. subquadratus Brönnimann

G. trilobus (Reuss)

GLOBOQUADRINA

G. altispira altispira (Cushman and Jarvis)

G. altispira globosa Bolli

G. dehiscens (Chapman, Parr, and Collins) 


\section{GLOBOROTALIA}

G. acrostoma Wezel

G. cerroazulensis cerroazulensis (Cole)

G. cerroazulensis cocoaensis Cushman

G. cerroazulensis cunialensis Toumarkine and Bolli

G. cerroazulensis pomeroli Toumarkine and Bolli

G. cibaoensis Bermudez

G. conoidea Walters

G. conomiozea Kennett

G. continuosa Blow

G. crassaformis (Galloway and Wissler)

G. fohsi fohsi Cushman and Ellisor

G. fohsi peripheroronda Blow and Banner

G. hirsuta (d'Orbigny)

G. increbescens (Bandy)

$G$. inflata (d'Orbigny)

G. juanai Bermudez and Bolli

G. cf. kugleri Bolli

G. lenguaensis Bolli

G. margaritae Bolli and Bermudez

G. menardii (Parker, Jones, and Brady)

G. merotumida Blow and Banner

G. miozea Finlay

$G$. cf. munda Jenkins

G. obesa Bolli

G. opima nana Bolli

G. opima opima Bolli

G. plesiotumida Blow and Banner

G. postcretacea (Myatliuk)

G. praehirsuta Blow

G. praemenardii Cushman and Stainforth

G. puncticulata (Deshayes)

G. ronda Blow

G. scitula (Brady)

G. siakensis LeRoy

G. tosaensis Takayanagi and Saito

G. truncatulinoides (d'Orbigny)

G. ventriosa Ogniben

GLOBOROTALOIDES

G. hexagona (Natland)

G. suteri Bolli

HANTKENINA

H. alabamensis Cushman

$H$. aragonensis Nuttall

H. liebusi Shokhina

H. longispina Cushman

HASTIGERINA

H. siphonifera (d'Orbigny)

MOROZOVELLA

M. acuta (Toulmin)

M. aequa (Cushman and Renz)

M. angulata (White)

$M$. aragonensis (Nuttall)

$M$. caucasica (Glaessner)

$M$. conicotruncata (Subbotina)

$M$. formosa gracilis (Bolli)

M. kolchidica (Morozova)

M. lensiformis (Subbotina)

$M$. marginodentata (Subbotina)

M. pusilla (Bolli)

M. quetra (Bolli)

M. simulatilis (Schwager)

M. spinulosa (Cushman)

M. subbotinae (Morozova)

$M$. uncinata (Bolli)

M. wilcoxensis (Cushman and Ponton)

NEOGLOBOQUADRINA

N. acostaensis (Blow)

$N$. atlantica (Berggren)
$N$. "du-pac" informal designation by Poore, 1979

$N$. dutertrei (d'Orbigny)

$N$. humerosa (Takayanagi and Saito)

N. pachyderma (Ehrenberg)

ORBULINA

O. suturalis Brönnimann

$O$. universa d'Orbigny

PLANOROTALITES

P. chapmani (Parr)

$P$. compressa (Plummer)

P. pseudomenardii (Bolli)

P. renzi (Bolli)

PRAEORBULINA

P. glomerosa (Blow)

PSEUDOHASTIGERINA

$P$ barbadoensis Blow

P. micra (Cole)

P. wilcoxensis (Cushman and Ponton)

SPHAEROIDINELLOPSIS

$S$. paenedehiscens Blow

$S$. seminulina (Schwager)

S. subdehiscens (Blow)

\section{SUBBOTINA}

S. inconstans (Subbotina)

S. pseudobulloides (Plummer)

$S$. triloculinoides (Plummer)

S. trinidadensis (Bolli)

S. velascoensis (Cushman)

TRUNCOROTALOIDES

$T$. collactea (Finlay)

T. rohri Brönniman and Bermudez

T. topilensis (Cushman)

TURBOROTALITA

T. quinqueloba (Natland)

ZEAUVIGERINA

Z. sp.

\section{ACKNOWLEDGMENTS}

We thank R. Z. Poore and W. H. Akers for their critical review of the manuscript, and J. Morley for helpful suggestions concerning sample preparation. The senior author is indebted to the co-chief scientists, P. C. de Graciansky and particularly C. W. Poag, for the opportunity to participate in this cruize. The cooperative and friendly attitude of other cruise participants, especially C. Müller and J. Sigal, is also appreciated.

\section{REFERENCES}

Auffret, G. A., and Pastouret, L., 1979. Upper Cretaceous to Quaternary sedimentary processes in the Bay of Biscay from textural, mineralogical, and coarse fraction studies. In Montadert, L., Roberts, D. G., et al., Init. Repts. DSDP, 48: Washington (U.S. Govt. Printing Office), 791-830.

Bé, A. W. H., 1959. Ecology of Recent planktonic foraminifera. Part 1-Areal distribution in the western North Atlantic. Micropaleontology, 5:77-100.

Berggren, W. A., 1972. Cenozoic biostratigraphy and paleobiogeography of the North Atlantic. In Laughton, A. S., Berggren, W. A., et al., Init. Repts. DSDP, 12: Washington (U.S. Govt. Printing Office), 965-1001.

, 1977. Atlas of Paleogene planktonic foraminifera. In Ramsay, A. T. S. (Ed.), Oceanic Micropaleontology: London (Academic Press), pp. 205-300.

Berggren, W. A., and Van Couvering, J. A., 1974. The late NeogeneBiostratigraphy, geochronology and paleoclimatology of the last 15 million years in marine and continental sequences. Paleogeogr., Paleoclimatol., Paleoecol., 16:1-216. 
Blow, W. H., 1969. Late middle Eocene to Recent planktonic foraminiferal biostratigraphy. In Brönnimann, P., Renz, H. H. (Eds.), Proc. First Int. Conf. Plank. Microfossils (Vol. 1): Leiden (Brill), pp. 199-422.

Bolli, H. M., 1957. Planktonic foraminifera from the Eocene Navet and San Fernando formations of Trinidad, B. W. I. In Loeblich, A. R., et al. (Eds.), Studies in Foraminifera. Bull. U.S. Nat. Mus., 215:155-172.

Cifelli, R., and Smith, R. K., 1970. Distribution of planktonic foraminifera in the vicinity of the North Atlantic Current. Smithsonian Contr. Paleobio., 4:1-52.

Fleisher, R. L., 1974. Cenozoic planktonic foraminifera and biostratigraphy, Arabian Sea Deep Sea Drilling Project, Leg 23A. In Whitmarsh, R. B., Weser, O. E., Ross, D. A., et al., Init. Repts. DSDP, 23: Washington (U.S. Govt. Printing Office), 1001-1072.

Hsü, K. J., He, Q., McKenzie, J. A., Weissert, H., Perch-Nielsen, K., Oberhänsli, H., Kelts, K., LaBrecque, J., Tauxe, L., Krähenbühl, U., Percival, S. F., Jr., Wright, R., Karpoff, A. M., Petersen, N., Tucker, P., Poore, R. Z., Gombos, A. M., Pisciotto, K., Carman, M. F., Jr., and Schreiber, E., 1982. Mass mortality and its environmental and evolutionary consequences. Science, 216:249-256.

Krasheninnikov, V. A., 1979. Stratigraphy and planktonic foraminifers of Cenozoic deposits of the Bay of Biscay and Rockall Plateau, DSDP Leg 48. In Montadert, L., Roberts, D. G., et al., Init. Repts. DSDP, 48: Washington (U.S. Govt. Printing Office), 431-450.

McGowran, B., 1968. Reclassification of early Tertiary Globorotalia. Micropaleontology, 14:179-198.

Murray, J. W., 1979. Cenozoic biostratigraphy and paleoecology of Sites 403 to 406 based on the foraminifera. In Montadert, L., Roberts, D. G., et al., Init. Repts. DSDP, 48: Washington (U.S. Govt. Printing Office), 415-430.
Poore, R. Z., 1979. Oligocene through Quaternary planktonic foraminiferal biostratigraphy of the North Atlantic: DSDP Leg 49. In Luyendyk, B. P.; Cann, J. R., et al., Init. Repts. DSDP, 49:Washington (U.S. Govt. Printing Office), 447-476.

Roegl, F., 1976. The occurrence of Bolboforma, a probable algal cyst, in the Antarctic Miocene of DSDP Leg 35. In Hollister, C. D., Craddock, C., et al., Init. Repts. DSDP, 35: Washington (U.S. Govt. Printing Office), 713-719.

Stainforth, R. M., Lamb, J. L., Luterbacher, H., Beard, J. H., and Jeffords, R. M., 1975. Cenozoic planktonic foraminiferal zonation and characteristics of index forms. Univ. Kansas Paleontol. Contr., Art. 62:1-425.

Toumarkine, M., and Bolli, H. M., 1970. Évolution de Globorotalia cerroazulensis (Cole) dans l'Éocène moyen et supérieur de Possagno (Italie). Rev. Micropaleontol., 13:131-145.

Vail, P. R., Mitchum, R. M., Jr., Todd, R. G., Widmier, J. M., Thompson, S., III, Sangree, J. B., Bubb, J. N., and Hatlelid, W. G., 1977. Seismic stratigraphy and gobal changes of sea level. In Payton, C. E. (Ed.), Seismic Stratigraphy-Applications to Hydrocarbon Exploration. Am. Assoc. Petrol. Geol. Mem., 26:49-212.

Vail, P. R., and Mitchum, R. M., 1979. Global cycles of relative changes of sea level from seismic stratigraphy. In Watkins, J. S., Montadert, L., and Dickerson, P. W. (Eds.), Geological and Geophysical Investigations of Continental Margins. Am. Assoc. Petrol. Geol. Mem., 29:469-472.

von Daniels, C. H., and Spiegler, D., 1974. Bolboforma n. gen. (Protozoa?)-eine neue stratigraphisch wichtige Gattung aus dem Oligozän/Miozän Nordwestdeutschlands. Paläontologische Zeitschrift, 48:57-76.

Date of Initial Receipt: September 14, 1982

Date of Acceptance: August 17, 1983 


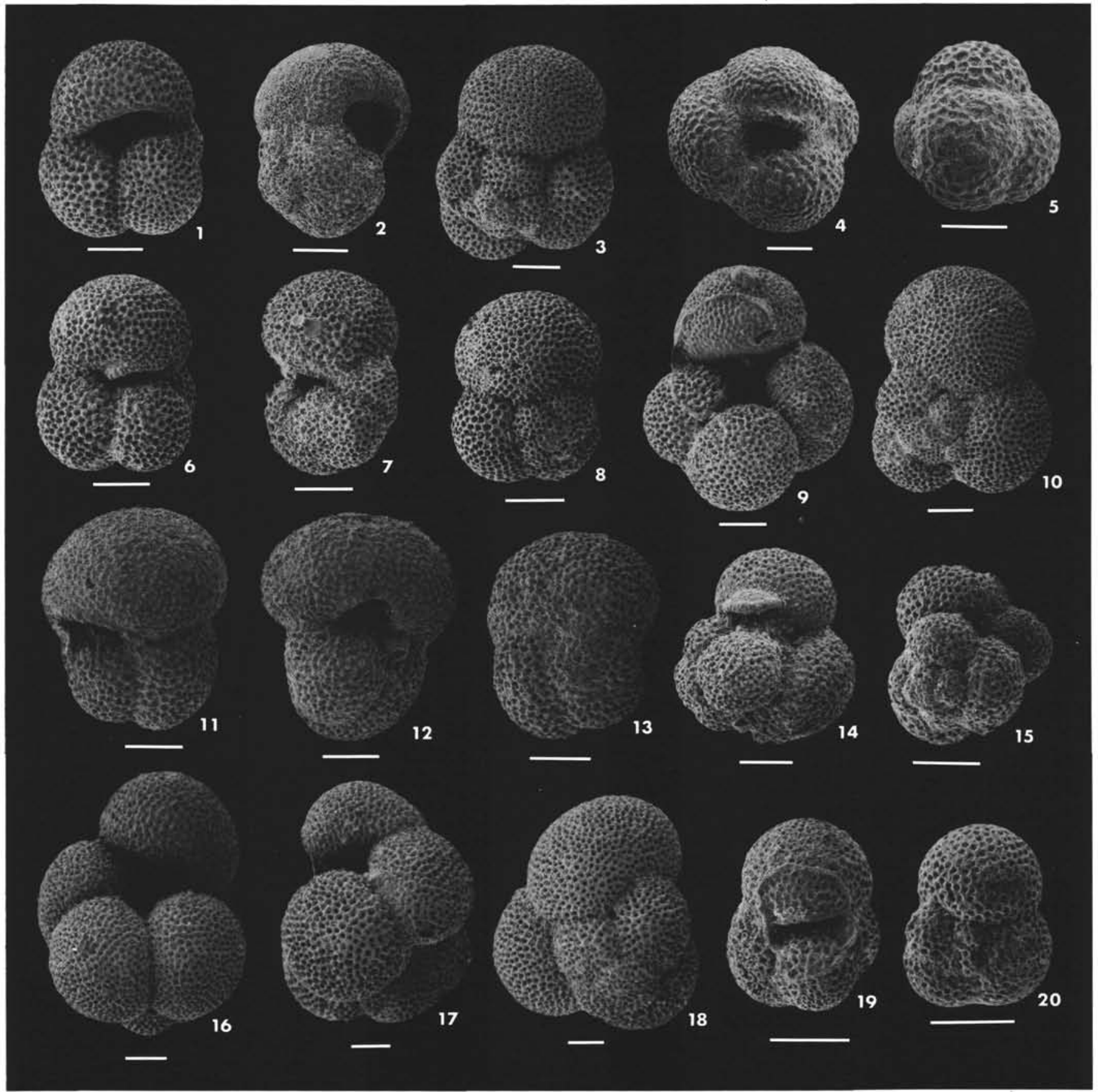

Plate 1. (Scale bars $=100 \mu \mathrm{m}$.) 1-3. Globigerina ampliapertura Bolli, (1) Sample 549A-9-5, 60-63 cm, umbilical view, (2) Sample 549A-10-5, 40$43 \mathrm{~cm}$, edge view, (3) Sample 549A-9-5, 60-63 cm, spiral view. 4-5. Globigerina angiporoides Hornibrook, Sample 549A-14-1, 30-33 cm, (4) umbilical view, (5) spiral view. 6-8. Globigerina eocaena Gümbell (emended Hagn and Lindenberg), Sample 548A-17-1, 66-69 cm, (6) umbilical view, (7) edge view, (8) spiral view. 9-10. Globigerina corpulenta Subbotina, Sample 548A-17-3, 66-69 cm, (9) umbilical view, (10) spiral view. 11-13. Globigerina frontosa Subbotina, Sample 548A-20-3, 53-55 cm, (11) umbilical view, (12) edge view, (13) spiral view. 14-15. Globigerina higginsi (Bolli), Sample 548A-20-3, 53-55 cm, (14) umbilical view, (15) spiral view. 16-18. Globigerina gortanii (Borsetti), Sample 549A-8-3, 50-53 cm, (16) umbilical view, (17) edge view, (18) spiral view. 19-20. Globigerina officinalis Subbotina, (19) Sample 549A-29,CC, umbilical view, (20) Sample 549A-17-1, 30-33 cm, spiral view. 


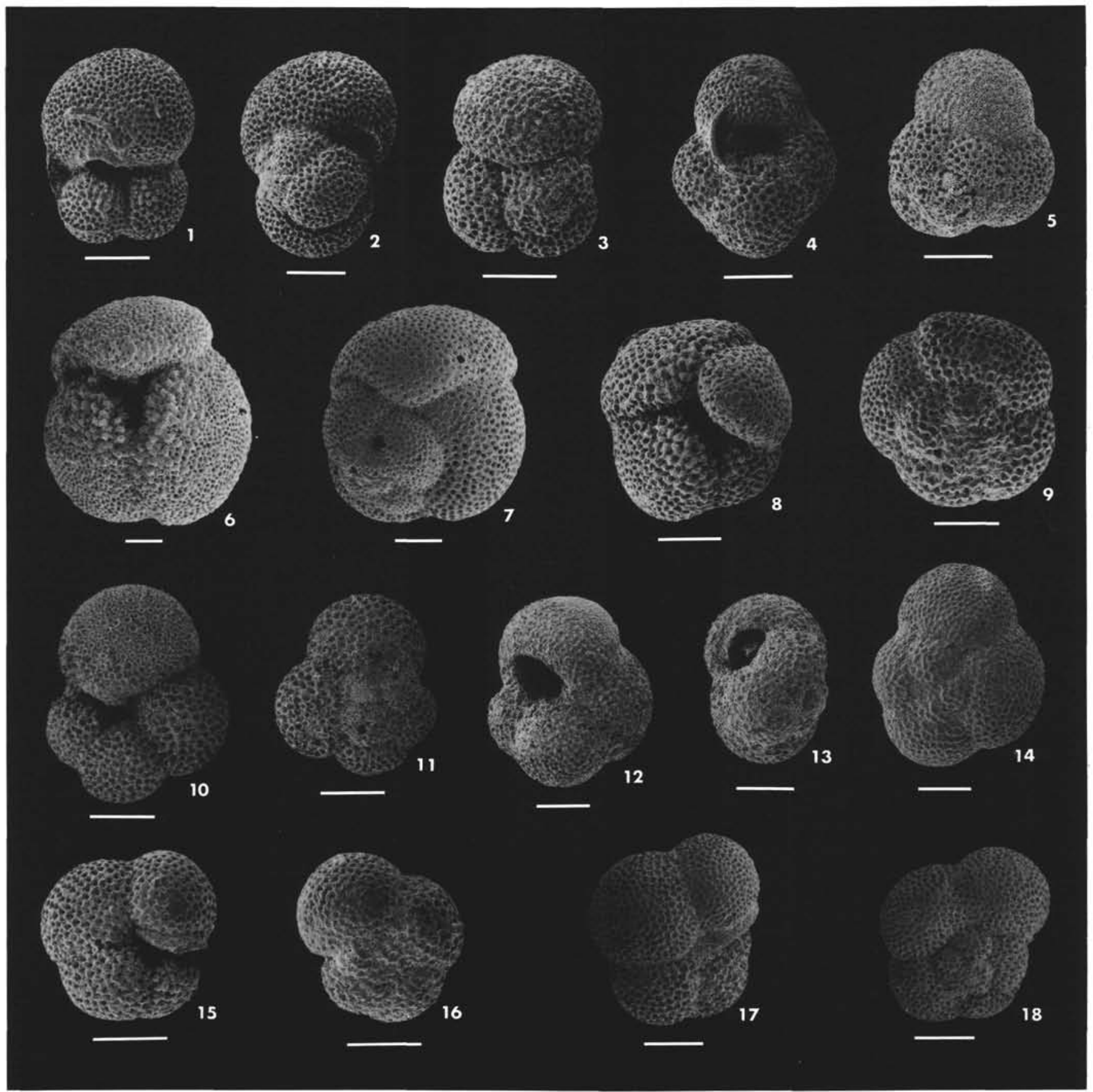

Plate 2. (Scale bars $=100 \mu \mathrm{m}$.) 1-3. Globigerina linaperta Finlay, (1) Sample 548A-22-6, 87-89 cm, umbilical view, (2-3) Sample 549-12-1, 49-52 $\mathrm{cm}$ (2, edge view; 3, spiral view). 4-5. Globigerina ouachitaensis Howe and Wallace, (4) Sample 549A-17-1, 30-33 cm, umbilical view, (5) Sample 549A-19-1, 30-33 cm, spiral view. 6-7. Globigerina tripartita Koch, (6) Sample 549A-8-3, 50-53 cm, umbilical view, (7) Sample 549A-9-3, 60-63 cm, spiral view. 8-9. Globigerina venezuelana Hedberg, Sample 548A-15-5, 58-60 cm, (8) umbilical view, (9) spiral view. 10-11. Globorotaloides suteri Bolli, (10) Sample 549A-7-6, 30-33 cm, umbilical view, (11) Sample 548A-17-1, 66-69 cm, spiral view. 12-14. Globigerina increbescens (Bandy), (12) Sample 549A-10-5, 60-63 cm, umbilical view, (13-14) Sample 549A-10-6, 40-43 cm (13, edge view; 14, spiral view). 15-16. Globorotalia opima nana Bolli, Sample 548A-16-2, 39-41 cm, (15) umbilical view, (16) spiral view. 17-18. Globorotalia opima opima Bolli, Sample 549A-9-2, 60-63 cm, (17) umbilical view, (18) spiral view. 


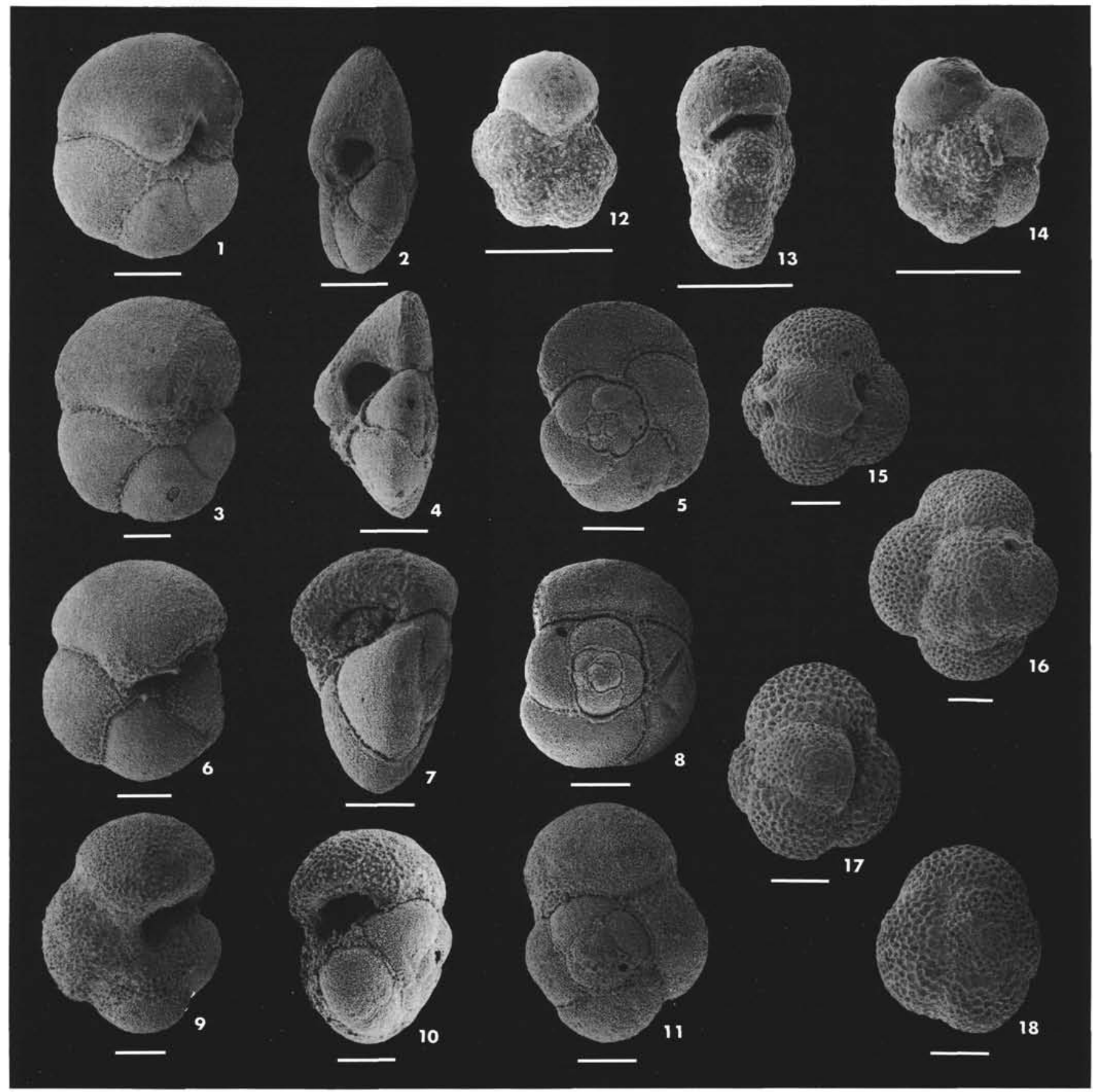

Plate 3. (Scale bars $=100 \mu \mathrm{m}$.) 1-2. Globorotalia cerroazulensis cunialensis Toumarkine and Bolli, Sample 549A-18-1, 30-33 cm, (1) umbilical view, (2) edge view. 3-5. Globorotalia cerroazulensis cocoaensis Cushman, (3) Sample 549A-28-1, 30-33 cm, umbilical view, (4) Sample 549A24-1, 30-33 cm, edge view, (5) Sample 549A-25-1, 30-33 cm, spiral view. 6-8. Globorotalia cerroazulensis cerroazulensis (Cole), (6,8) Sample 549A-32-1, 50-53 cm (6, umbilical view, 8, spiral view), (7) Sample 549A-24-1, 30-33 cm, edge view. 9-11. Globorotalia cerroazulensis pomeroli Toumarkine and Bolli, (9-10) Sample 549-2-1, 27-30 cm, (9, umbilical view; 10, edge view), (11) Sample 549-4-1, 7-10 cm, spiral view. 12-14. Globorotalia postcretacea (Myatliuk), Sample 549A-11-6, 30-33 cm, (12) umbilical view, (13) edge view, (14) spiral view. 15-16. Catapsydrax dissimilis (Cushman and Bermudez), Sample 549A-9-4, 60-63 cm, (15) umbilical view, (16) spiral view. 17-18. Catapsydrax unicavus Bolli, Loeblich, and Tappan, Sample 549A-9-2, 60-63 cm, (17) umbilical view, (18) spiral view. 

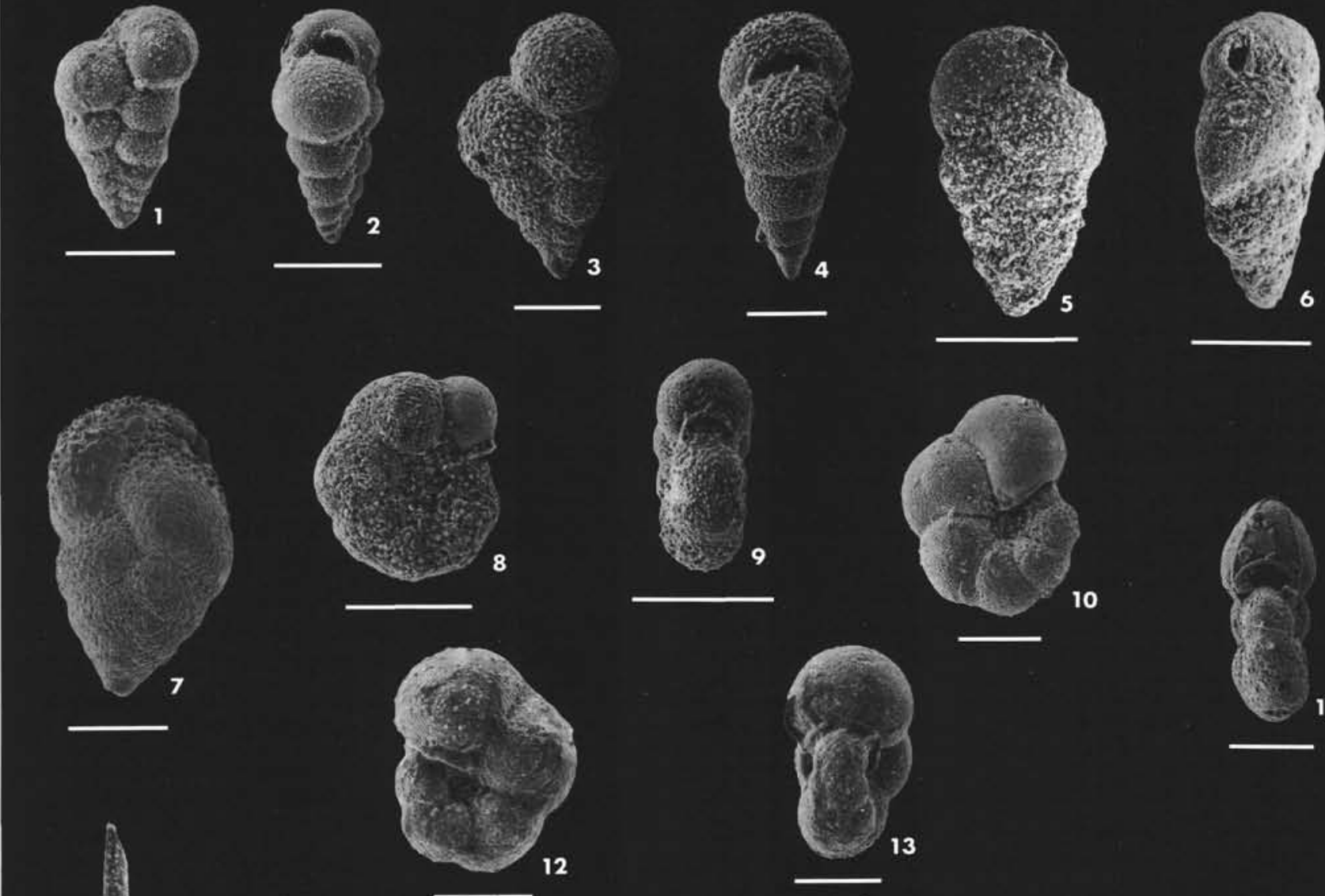

\section{0}
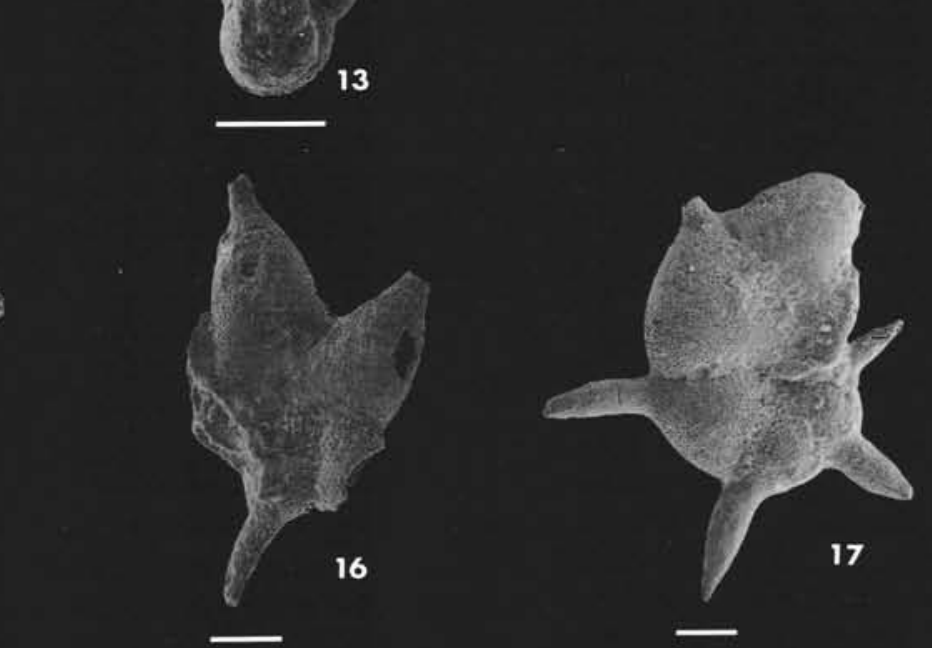

14
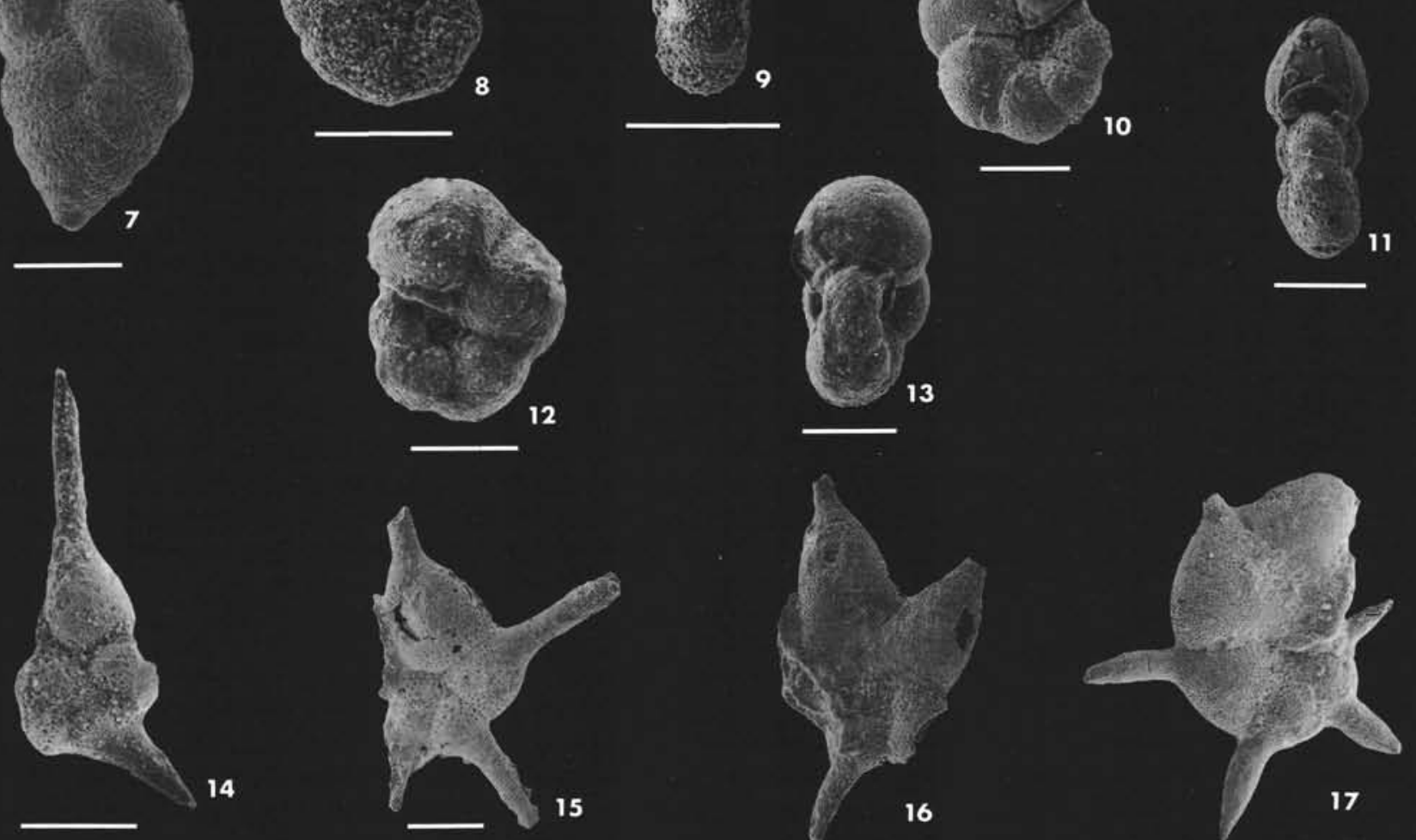

2

Plate 4. (Scale bars $=100 \mu \mathrm{m}$.) 1-2. Chiloguembelina cubensis (Palmer), Sample 548A-17-1, 66-69 cm, (1) side view, (2) edge view. 3-4. Chiloguembelina wilcoxensis (Cushman and Ponton), Sample 548-28-3, 62-63 cm, (3) side view, (4) edge view. 5-6. Chiloguembelina midwayensis (Cushman), (5) Sample 550-41-2, 114-116 cm, side view, (6) Sample 550-38-2, 54-56 cm, edge view. 7. Zeauvigerina sp., Sample 549-13-3, 56$59 \mathrm{~cm}$, side view. 8-9. Pseudohastigerina barbadoensis Blow, Sample 549A-11-6, 30-33 cm, (8) side view, (9) edge view. 10-11. Pseudohastigerina micra (Cole), (10) Sample 548A-17-2, 66-69 cm, side view, (11) Sample 548A-18-3, 58-60 cm, edge view. 12-13. Pseudohastigerina wilcoxensis (Cushman and Ponton), Sample 548A-23-1, 62-66 cm, (12) side view, (13) edge view. 14. Hantkenina longispina Cushman, Sample 549-6-6, 63-66 cm, side view. 15. Hantkenina liebusi Shokhina, Sample 548A-20-1, 85-87 cm, side view. 16. Hantkenina aragonensis Nuttall, Sample 548A-20-3, 53-55 cm, side view. 17. Hantkenina alabamensis Cushman, Sample 549-5-3, 48-50 cm, side view. 


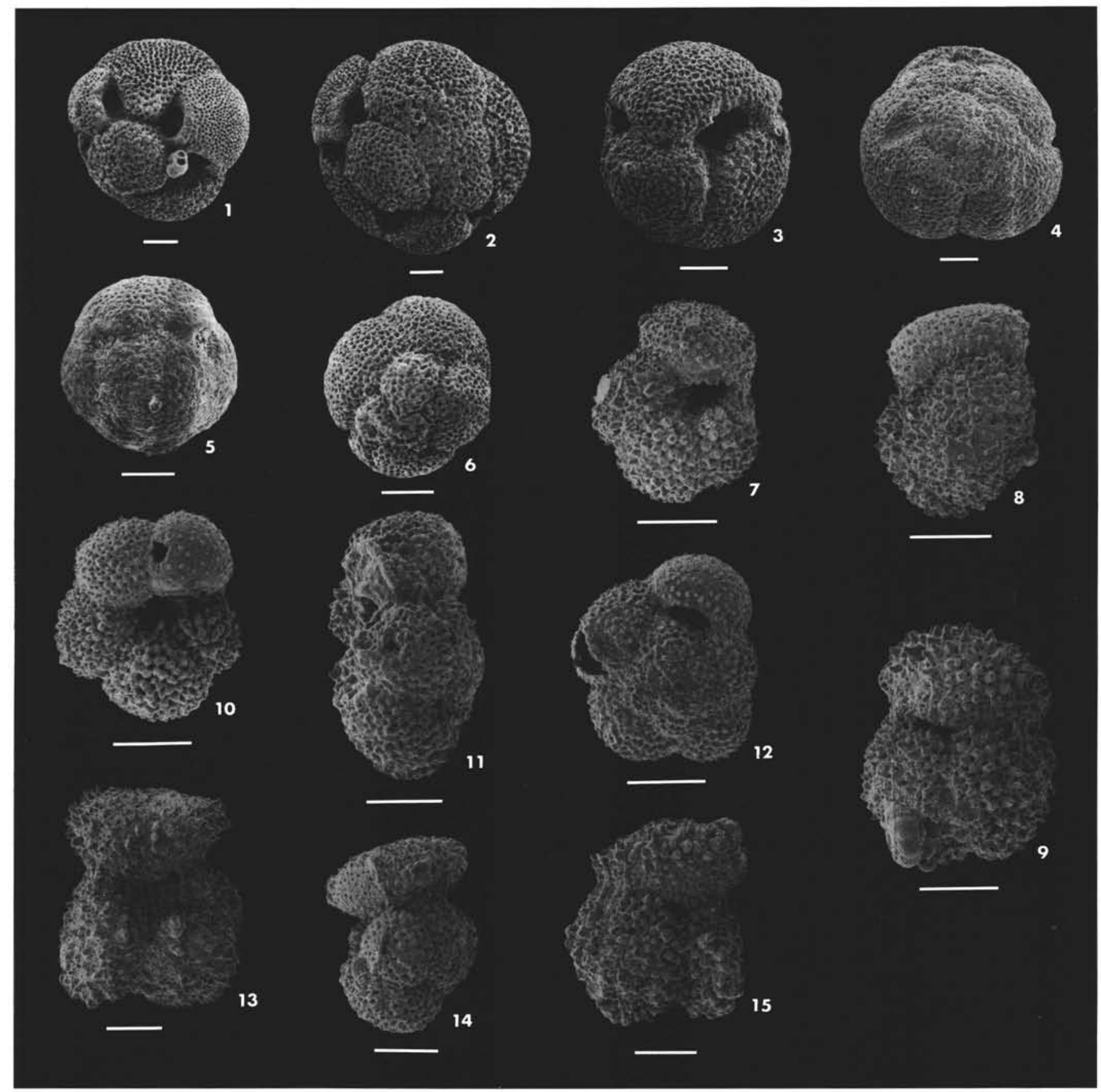

Plate 5. (Scale bars $=100 \mu \mathrm{m}$.) 1-2. Globigerinatheka barri Brönnimann, Sample 549A-36,CC, (1) slightly oblique view, (2) spiral view. 3-4. Globigerinatheka index (Finlay), (3) Sample 548A-17-2, 66-69 cm, umbilical view, (4) Sample 548A-18-1, 67-69 cm, spiral view. 5-6 Globigerinatheka subconglobata (Shutskaya), (5) Sample 549-5-4, 48-50 cm, umbilical view, (6) Sample 548A-18-3, 58-60 cm, spiral view. 7-9. Truncorotaloides collactea (Finlay), Sample 548A-18-2, 65-68 cm, (7) umbilical view, (8) edge view, (9) spiral view. 10-12. Truncorotaloides rohri Brönnimann and Bermudez, (10-11) Sample 548A-18-2, 65-68 cm, (10, umbilical view; 11, edge view), (12) Sample 548A-20-3, 53-55 cm, spiral view. 13-15. Truncorotaloides topilensis (Cushman), (13) Sample 548A-18-3, 58-60 cm, umbilical view, (14-15) Sample 548A-18-2, 65-68 cm, (14, edge view; 15 , spiral view). 


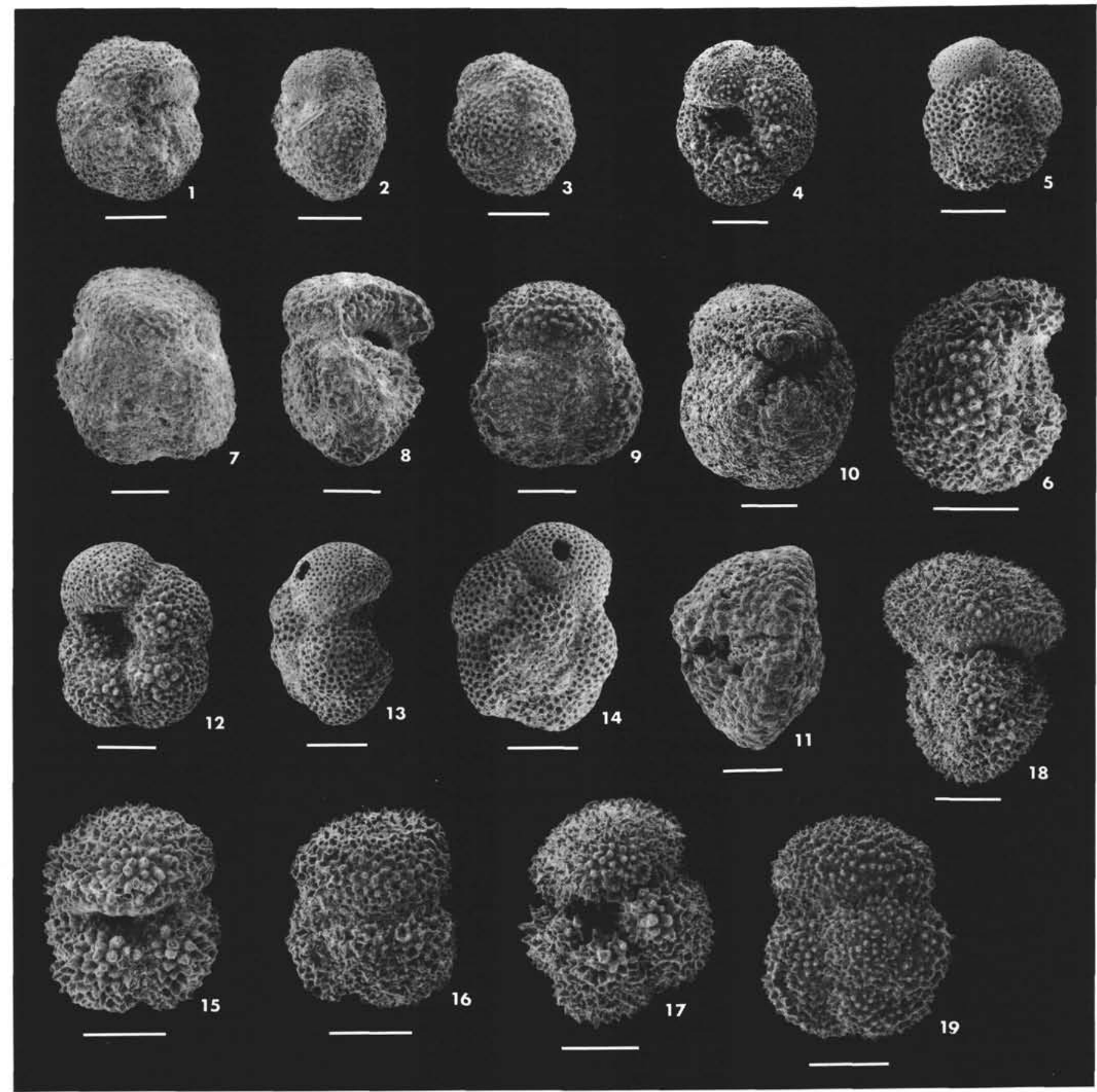

Plate 6. (Scale bars $=100 \mu \mathrm{m}$.) 1-3. Acarinina broedermanni (Cushman and Bermudez), Sample 549-8-1, 75-78 cm, (1) umbilical view, (2) edge view, (3) spiral view. 4-6. Acarinina mckannai (White), (4,6) Sample 549-16-4, 57-60 cm, (4, umbilical view; 6, edge view), (5) Sample 548A-285, 62-65 cm, spiral view. 7-9. Acarinina bullbrooki (Bolli), Sample 549-5-5, 48-50 cm, (7) umbilical view, (8) edge view, (9) spiral view. 1011. Acarinina nitida (Martin), Sample 549-13-1, 52-55 cm, (10) umbilical view, (11) edge view. 12-14. Acarinina pentacamerata (Subbotina), Sample 548A-20-1, 85-87 cm, (12) umbilical view, (13) edge view, (14) spiral view. 15-16. Acarinina primitiva (Finlay), (15) Sample 548A-23-1, 62-66 cm, umbilical view, (16) Sample 548A-25-5, 52-56 cm, spiral view. 17-19. Acarinina pseudotopilensis Subbotina, Sample 549-13-1, 52-55 $\mathrm{cm}$, (17) umbilical view, (18) edge view, (19) spiral view. 


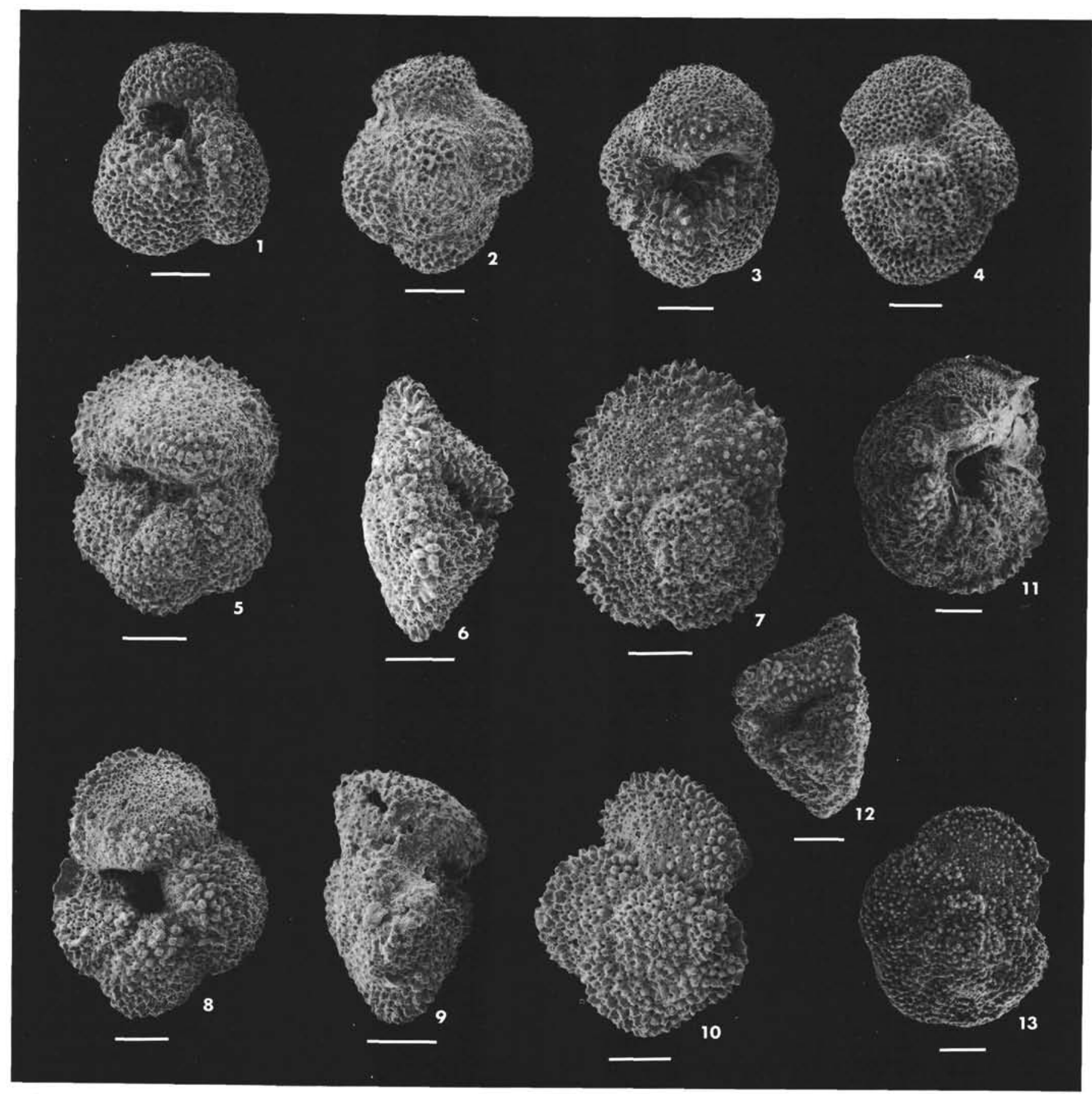

Plate 7. (Scale bars $=100 \mu \mathrm{m}$.) 1-2. Acarinina soldadoensis angulosa (Bolli), (1) Sample 548A-24-6, 17-21 cm, umbilical view, (2) Sample 548A24-3, 14-18 cm, spiral view. 3-4. Acarinina soldadoensis soldadoensis (Brönnimann), (3) Sample 548A-24-6, 17-21 cm, umbilical view, (4) Sample 548A-23-1, 62-66 cm, spiral view. 5-7. Morozovella aequa (Cushman and Renz), Sample 549-16-5, 57-60 cm, (5) umbilical view, (6) edge view, (7) spiral view. 8-10. Morozovella angulata (White), Sample 548A-28-4, 42-45 cm, (8) umbilical view, (9) edge view, (10) spiral view. 11-13. Morozovella aragonensis (Nuttall), (11-12) Sample 548A-22-5, 87-89 cm, (11, umbilical view; 12, edge view), (13) Sample 548A-23-1, 62$66 \mathrm{~cm}$, spiral view. 


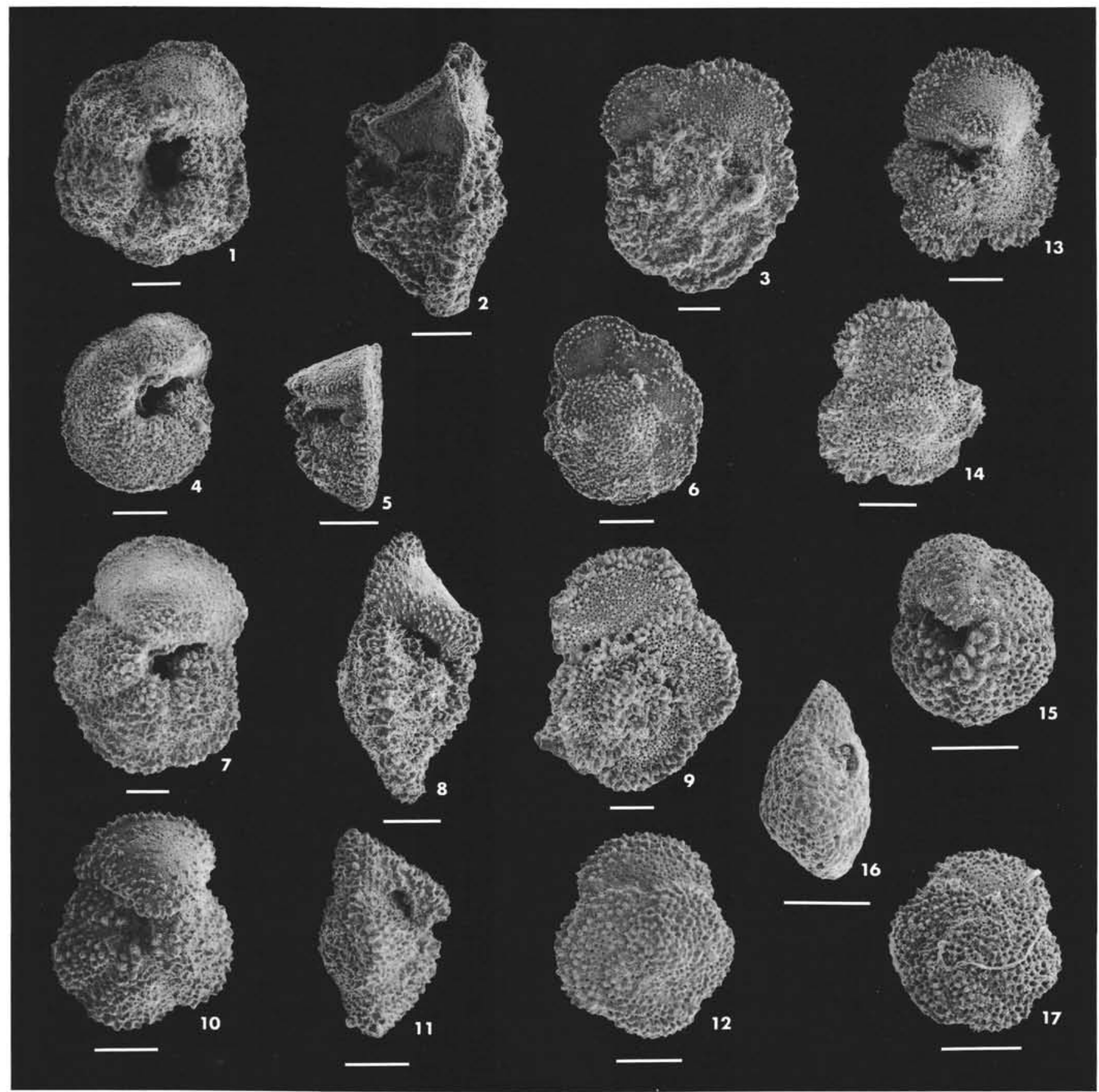

Plate 8. (Scale bars $=100 \mu \mathrm{m}$.) 1-3. Morozovella caucasica (Glaessner), (1) Sample 549-10-6, 79-83 cm, umbilical view, (2-3) Sample 548A-22-5, $87-89 \mathrm{~cm}$ (2, edge view; 3, spiral view). 4-6. Morozovella conicotruncata (Subbotina), (4-5) Sample 549-16-4, 57-60 cm (4, umbilical view; 5, edge view), (6) Sample 549-16-5, 57-60, spiral view. 7-9. Morozovella formosa gracilis (Bolli), (7,9) Sample 549-12-4, 47-50 cm (7, umbilical view; 9, spiral view), (8) Sample 549-13-1, 52-55 cm, edge view. 10-12. Morozovella kolchidica (Morozova), Sample 549-20-3, 65-67 cm, (10) umbilical view, (11) edge view, (12) spiral view. 13-14. Morozovella marginodentata (Subbotina), Sample 549-13-1, 52-55 cm, (13) umbilical view, (14) spiral view. 15-17. Morozovella pusilla pusilla (Bolli), (15) Sample 549-20-5, 18-20 cm, umbilical view, (16) Sample 549-21-2, 9-12 $\mathrm{cm}$, edge view, (17) Sample 549-16-5, 57-60 cm, spiral view. 


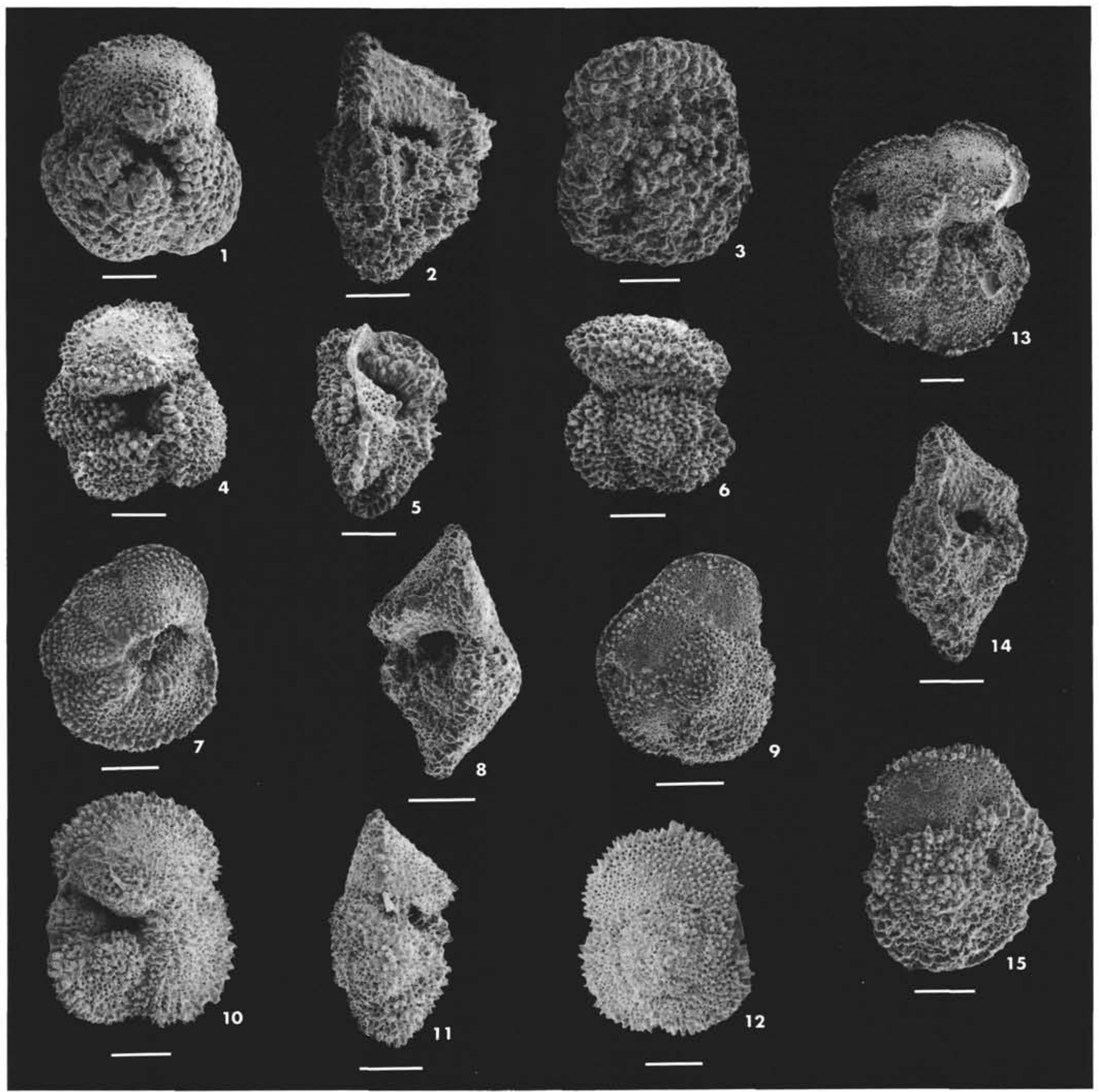

Plate 9. (Scale bars $=100 \mu \mathrm{m}$.) 1-3. Morozovella lensiformis (Subbotina), (1,3) Sample 548A-27-1, 60-62 cm (1, umbilical view; 3, spiral view), (2) Sample 548A-28-3, 70-74 cm, edge view. 4-6. Morozovella quetra (Bolli), Sample 550-33-3, 59-61 cm, (4) umbilical view, (5) edge view, (6) spiral view. 7-9 Morozovella simulatilis (Schwager), Sample 549-16-4, 57-60 cm, (7) umbilical view, (8) edge view, (9) spiral view. 10-12. Morozovella subbotinae (Morozova), Sample 548A-28-3, 70-74 cm, (10) umbilical view, (11) edge view, (12) spiral view. 13-15. Morozovella spinulosa (Cushman), (13,15) Sample 548A-22-5, 87-89 cm (13, umbilical view; 15, spiral view), (14) Sample 548A-19-1, 38-40 cm, edge view. 


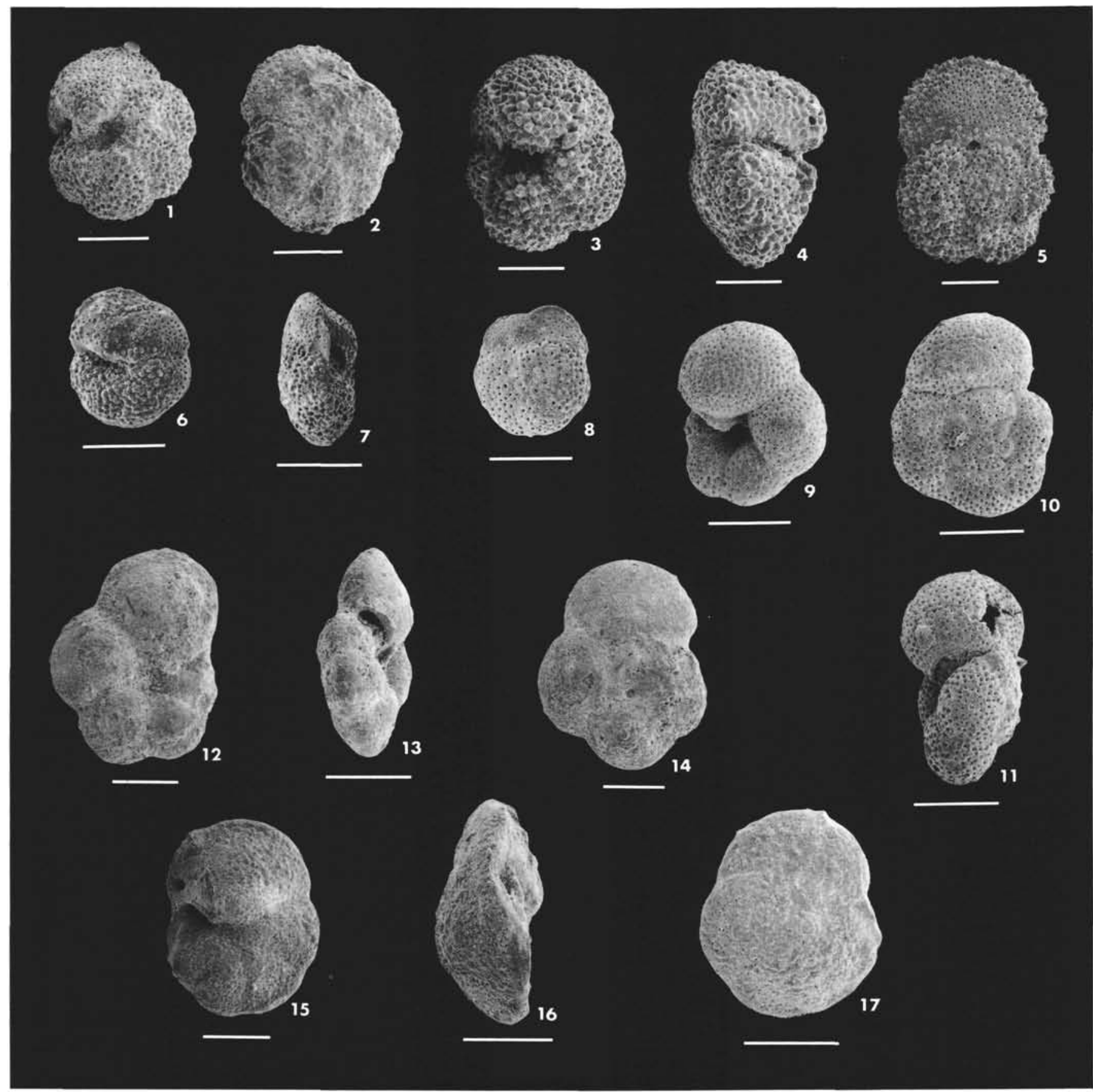

Plate 10. (Scale bars $=100 \mu \mathrm{m}$.) 1-2. Morozovella uncinata (Bolli), (1) Sample 550-37-5, 59-61 cm, umbilical view, (2) Sample 550-38-3, 54-56 $\mathrm{cm}$, spiral view. 3-5. Morozovella wilcoxensis (Cushman and Ponton), (3-4) Sample 549-16-3, 52-56 cm (3, umbilical view; 4, edge view), (5) Sample 548A-28-4, 42-45 cm, spiral view. 6-8. Planorotalites renzi (Bolli), Sample 549A-42-1, 18-20 cm, (6) umbilical view, (7) edge view, (8) spiral view. 9-11. Planorotalites chapmani (Parr), Sample 548A-28-3, 70-74 cm, (9) umbilical view, (10) edge view, (11) spiral view. $12-14$. Planorotalites compressa (Plummer), (12,14) Sample 550-37-1, 59-61 cm (12, umbilical view; 14, spiral view), (13) Sample 550-38-3, 54-56 cm, edge view. 15-17. Planorotalites pseudomenardii (Bolli), Sample 549-20-3, 65-67 cm, (15) umbilical view, (16) edge view, (17) spiral view. 


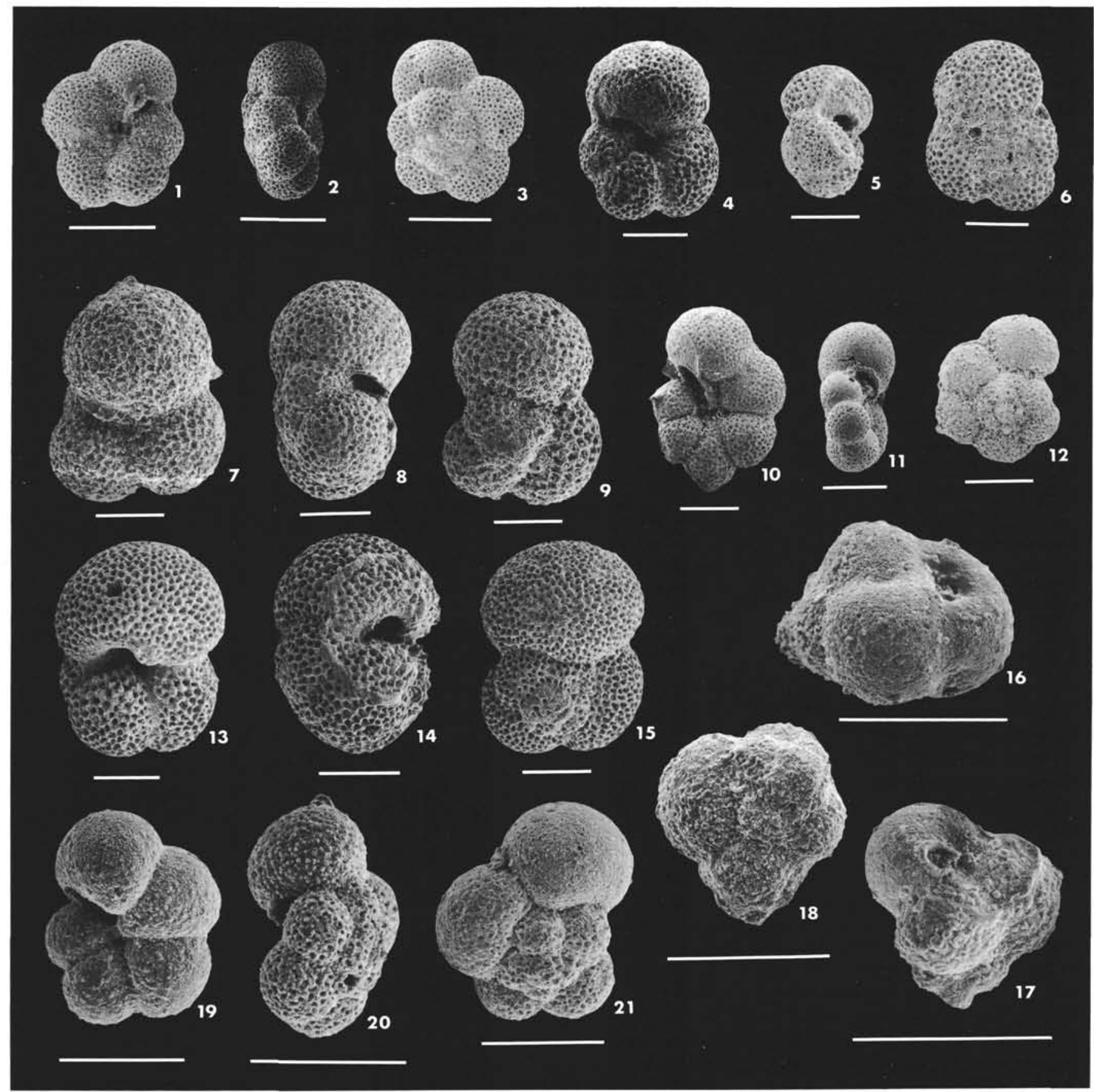

Plate 11. (Scale bars $=100 \mu \mathrm{m}$.) 1-3. Subbotina inconstans (Subbotina), Sample 548A-28-7, 28-30 cm, (1) umbilical view, (2) edge view, (3) spiral view. 4-6. Subbotina pseudobulloides (Plummer), Sample 550-37-5, 59-61 cm, (4) umbilical view, (5) edge view, (6) spiral view. 7-9. Subbotina triloculinoides (Plummer), (7) Sample 550-37-1, 59-61 cm, umbilical view, (8-9) Sample 550-38-2, 54-56 cm (8, edge view; 9, spiral view). 10-12. Subbotina trinidadensis (Bolli), Sample 548A-28-7, 28-30 cm, (10) umbilical view, (11) edge view, (12) spiral view. 13-15. Subbotina velascoensis (Cushman), Sample 548A-28-5, 62-65 cm, (13) umbilical view, (14) edge view, (15) spiral view. 16-18. Eoglobigerina daubjergensis (Brönnimann), Sample 550-40-1, 5-8 cm, (16) lateral view, (17) umbilical view, (18) spiral view. 19-21. Eoglobigerina eugubina (Luterbacher and Premoli Silva), Sample 550B-2-3, 31-33 cm, (19) umbilical view, (20) edge view, (21) spiral view. 